IRSH 54 (2009), pp. 459-497 doi:I0.I0I7/So020859009990344

(C) 2009 Internationaal Instituut voor Sociale Geschiedenis

\title{
Swing, Swing Redivivus, or Something After Swing? On the Death Throes of a Protest Movement, December I 830-December I $833^{*}$
}

\author{
CARL J. GRIFFIN \\ School of Geography, Archaeology and Palaeoecology, \\ Queen's University, Belfast \\ E-mail: carl.griffin@qub.ac.uk
}

Summary: Published in 1969, Hobsbawm and Rudés Captain Swing remains the sole national account of the so-called "Swing riots" that diffused throughout most of rural southern, central, and eastern England in the autumn and winter of i 830 . Whilst much revisionist work has been published since, Hobsbawm and Rudés contention that Swing's brutal judicial repression effectively ended the protests has remained essentially unchallenged. Through an archival re-examination of the resort to protest between the i 830 trials and December I 833 , this paper contends that the received understanding that $S_{w i n g}$ was crushed is too simplistic. In some locales, Swing maintained its momentum, in others it revived. Swing also morphed into different forms, both real and phantasmagorical. But the intensity of protests did decline. By the autumn of $\mathrm{I} 833$, protests were less frequent, now representing a fractured, isolated spatiality instead of a coherent protest campaign.

\section{INTRODUCTION}

Since the publication of E.P. Thompson's seminal The Making of the English Working Class in 1963, studies of popular protest have assumed a central position in social histories of late eighteenth- and early nineteenthcentury rural England. ${ }^{I}$ Whilst this vibrant field of research has produced many fine studies, arguably the most influential - and most widely cited study remains Eric Hobsbawm and George Rudé's forty-year-old Captain Swing. In part, this longstanding impact is a testimony to the quality of the authors' research and writing. Perhaps even more important though is the fact that their book remains the only national account of the so-called

\footnotetext{
* An earlier version of this paper was delivered at the 2008 European Social Science History Conference, Lisbon.

I. E.P. Thompson, The Making of the English Working Class (London, 1963).
} 
"Swing riots" of $1830 .^{2}$ Unlike earlier outbursts of rural protest, most notably the "Bread and Blood" riots of I8I6 and the East Anglian protests of $\mathrm{I} 822$, Swing was not confined to a single region. Instead, after emerging from Kent in early November I 830, it spread throughout the whole of southern, central, and eastern England in little more than six weeks.

Swing has also captured the popular imagination: Captain Swing remains one of the few works of academic history to enter the best-seller lists. Moreover, it is important to remember that Swing remains the biggest single episode of machine-breaking in British history. Immiserated by mass un- and under-employment and increasingly parsimonious poor relief, both functions of the acute post-Napoleonic agrarian depression, rural workers responded by breaking labour-sapping threshing machines and calling for higher wages and more generous relief. Many farmers and overseers of the poor who flouted customary codes of reciprocity and responsibility were also visited by night-time incendiarists. Some even received threatening letters signed by the mythical "Swing". The protests also coincided with, and contributed towards, what Rudé claimed was the moment that England came closest to a continental-style revolution. ${ }^{3}$ In short, Swing was an exceptional outbreak of rural protest. It was, as the Hammonds had noted in their earlier study, the last (widespread) rising of the English labourers. ${ }^{4}$

Whilst we know much about the intensity, geography, and sociology of Swing, the way in which it ended remains a source not so much of conjecture as almost total supposition. The received understanding is as follows. Between i 8 December I 830 and I4 January I83 I, 992 criminal cases were tried in I I different courts held in six different towns in the English counties of Berkshire, Buckinghamshire, Dorset, Hampshire, and Wiltshire. The sentence of death was passed on 227 individuals, of whom only 5 were hanged; 359 were transported to New South Wales or Van Diemen's Land; 254 were jailed, and 2 were fined. According to Hobsbawm and Rudé, the "draconian punishments distributed [...] [and] the deportation of hapless men and boys to antipodean semi-slavery" helped to thoroughly demoralize rural workers. ${ }^{5}$ In those counties in which activists were not tried at government-sponsored Special Commissions but instead at the regular provincial courts of Quarter Sessions and Assize, Swing is supposed to have "died a natural death", little affected by the "active intervention of the government or magistrates".

2. Eric Hobsbawm and George Rudé, Captain Swing (London, 1969).

3. George Rudé, The Crowd in History: A Study of Popular Disturbances in France and England, $1730-1848$ (London, 1964).

4. John and Barbara Hammond, The Village Labourer (London, I9I I, repr. 1978).

5. Hobsbawm and Rudé, Captain Swing, p. 281. 
Swing, so such an analysis goes, was either stopped in its tracks or, instead, achieved its multifarious aims and therefore faded. ${ }^{6}$

All such theories are necessarily predicated on the understanding that Swing stopped at some point in the winter of I 830 . For instance, John Stevenson in his survey of popular disturbances in late eighteenth and early nineteenth-century England refers to the Swing "months". Such an interpretation would be understandable if the "bitter vindictiveness" of the Special Commissions snuffed out what will there was left to protest. But Hobsbawm and Rudé, in common with more recent historians of Swing, have stated that the response to this brutal judicial repression provoked a resort to the weapons of rural terrorism. ${ }^{8}$ In the initial Swing centres, the interplay between protest and judicial response was very different. After the "lenient" sentences - the phrase is Home Secretary Peel's - handed down at very first Swing trial, protests spread beyond east Kent for the first time. Moreover, according to Hobsbawm and Rudé, whilst the will to protest in Kent was not altogether stamped out in the winter of 1830 , the "few local revivals" were mere "afterglows of the greater fire of 1830 ". 9 A brief analysis of their tabulations is instructive. Between Christmas I830 and the end of $183 \mathrm{I}$, in the south-eastern counties of Hampshire, Kent, Sussex, and Surrey, there were, they claimed, twelve further incendiary fires, two "Swing" letters sent, five further "riots" and six machines destroyed. ${ }^{10}$ These were carried out by "the wild, independent, savage marginal men $[\ldots]$ and the youths". ${ }^{\text {II }}$ The sense of injustice may have lived on for decades but, if such figures are correct, the afterglow was not only short-lived but also remarkably socially inert.

\footnotetext{
6. Ibid., p. 233.

7. John Stevenson, Popular Disturbances in England I700-I832 (London, 1992), p. 270.

8. Ibid., ch. I5; Andrew Charlesworth, An Atlas of Rural Protest in Britain I548-I900 (London, I983), p. I5 I; Roger Wells, "Social Protest, Class, Conflict and Consciousness, in the English Countryside", in Mick Reed and Roger Wells (eds), Class, Conflict and Protest in the English Countryside, I700-I880 (London, I990), pp. I2 I-2 I4, I66-I69, I87-190; idem, "The Moral Economy of the English Countryside", in Adrian Randall and Andrew Charlesworth (eds), Moral Economy and Popular Protest: Crowds, Conflict and Authority (Basingstoke, 2000), pp. 209-272, 246-247; Adrian Randall and Edwina Newman, "Protest, Proletarians and Paternalists: Social Conflict in Rural Wiltshire 1830-1850", Rural History, 6 (1995), pp. 205-227; David Kent and Norma Townsend, Convicts of the Eleanor: Protest in Rural England, New Lives in Australia (London, 2002). John and Barbara Hammond also reached a similar conclusion: "The riots were over, but the fires continued"; Village Labourer, p. 237. 9. Hobsbawm and Rudé, Captain Swing, p. 283. See also Andrew Charlesworth, Social Protest in a Rural Society (Norwich, 1979).

Io. These figures are derived from the extensive tabulations contained in Hobsbawm and Rudé, Captain Swing, Appendix 3, pp. 3 I 2-358. The figure of twelve incendiary fires includes a sum of two fires for the "several fires" reported to have occurred in Kent in June I 831; p. 357. I I. Ibid., p. 287.
} 
It is important to note though that Hobsbawm and Rudés tabulations for Swing incidents are no longer accepted as being definitive. Roger Wells has even suggested that for I83 I their tables are "hopelessly defective". ${ }^{12}$ Notwithstanding these long-held positions and the many revisionist accounts of Swing, the suggestion that the judicial and quasimilitaristic "repression" of late I 830 might not have been as successful in stemming protest has not yet been systematically explored. ${ }^{13}$

The aim of this paper is thus: to examine the resort to protest beyond Swing's supposed repression. If the trials did represent the end of Swing, then the protests that followed were something post-Swing. But, as we know, Swing-like incidents occurred both during the immediate aftermath of the trials and in the summers of $\mathrm{I}_{3} \mathrm{I}_{\mathrm{I}}$ and $\mathrm{I}_{3} \mathrm{3}_{2}$. Were such incidents post-Swing? Did they represent attempts to revive Swing? Or were they instead evidence that Swing had never actually died? Before answering these questions, it is necessary to question whether - and if so, how - the protests of late i 830 represented a "movement" as opposed to a random and spontaneous outpouring of feeling.

The focus is south-eastern England (see Figures I and 2), the region where Swing started and where it was met by arguably the largest range of judicial responses: the bitter vindictiveness of the Hampshire Special Commission, the first and harshest of all Special Commissions, through the relatively light judicial touch in Sussex, to the supposed "unparalleled leniency" shown to the first Kentish machine-breakers. Analysing the south-east thereby allows us to examine the impact of different strategies of repression. The timeframe adopted is 25 December 1830 , the mid point, and break, of the Winchester Special Commission, to the end of 1833 . Beyond this date, the imposition of the New Poor Law provoked a wave of quite different protests. It is important to note that whilst the final Special Commission, held at Aylesbury, did not close until mid January I 83 I, there is no evidence to suggest that, after the initial nationwide shock at the ferocity of the Winchester sentences, the ensuing Special Commissions created anything other than localized sensations. In the south-east, therefore, the end of the Winchester Special Commission and the ensuing executions rather than the end of all the Special Commissions marked the end of the repression. Indeed, as will be shown, south-eastern protestors did not wait for the judges to pass the final sentences at Aylesbury to react to the government-sponsored repression.

I 2. Carl Griffin, “'There Was No Law to Punish that Offence': Re-Assessing 'Captain Swing': Rural Luddism and Rebellion in East Kent, I 830-3 I”, Southern History, 22 (2000), pp. I 3 I-I63, I46; Wells, "Social Protest, Class, Conflict and Consciousness", p. i68.

I3. Charlesworth, Social Protest in a Rural Society; Randall and Newman, "Protest, Proletarians and Paternalists"; Wells, "Social Protest, Class, Conflict and Consciousness"; idem, "Moral Economy of the English Countryside". 


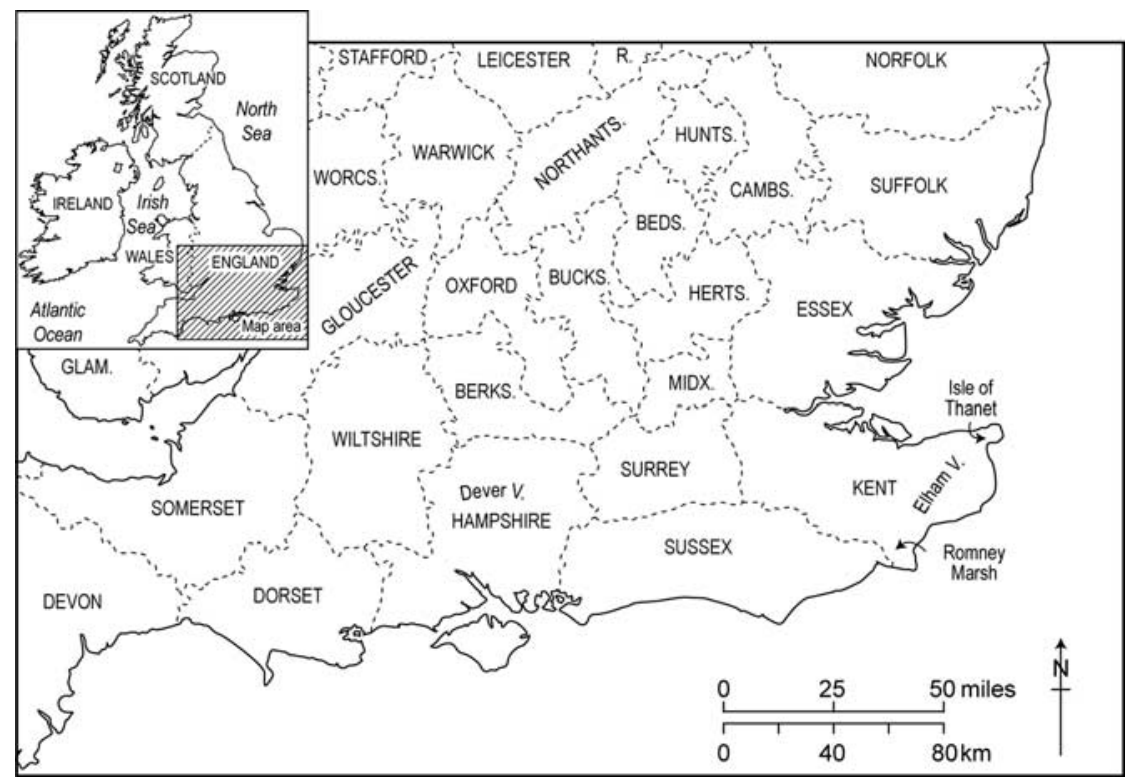

Figure I. County boundaries of southern England and areas mentioned in the text.

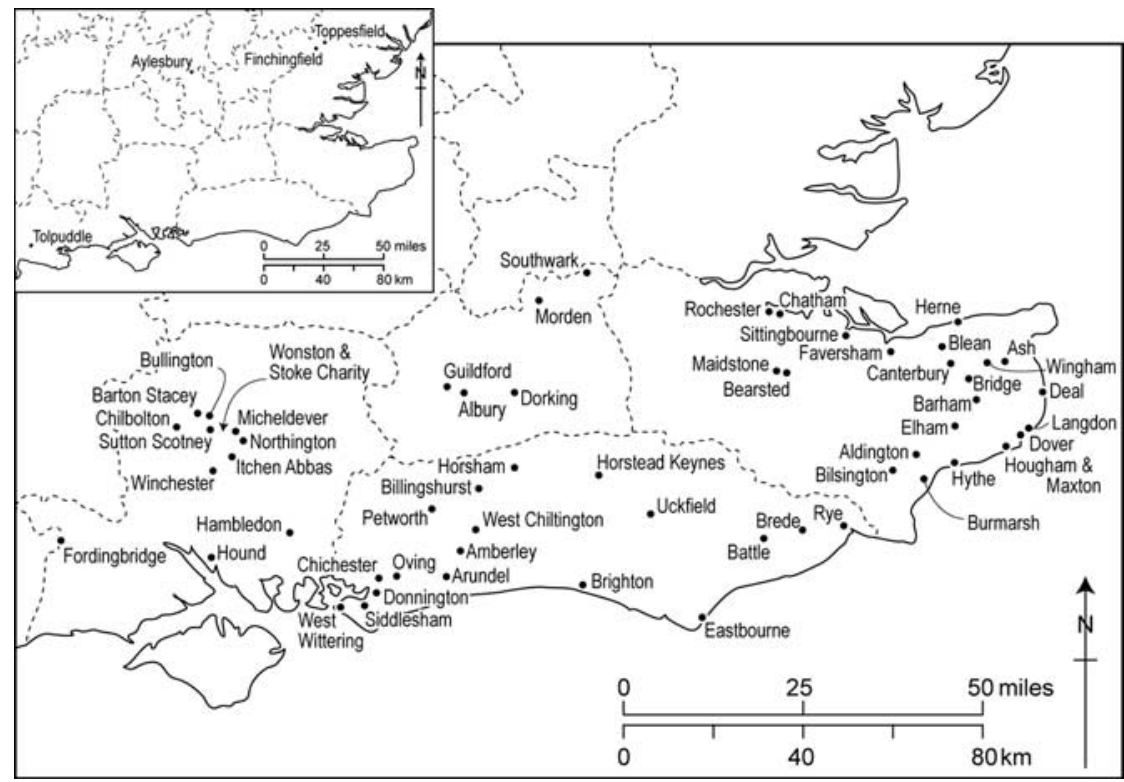

Figure 2. Parishes and places mentioned in the text. 
Any attempt to think through how a protest movement ends necessarily needs to ask both whether the subject of analysis genuinely represented a movement as opposed to a localized or disjointed series of events. And, if so, what protest techniques and discourses defined the movement. What follows rather than being arranged chronologically, starts by asking these questions in relation to social movement theory, before going on to examine the post-trial resort to protest. This second section is divided into five sub-sections. The first applies the social-movement understandings developed in section I to analyse the trajectory of protest practices between I 83 I and I 833 . The second examines the response to repression, whilst the third and fourth sub-sections ask whether protests in the posttrial period represented an attempt to address "unfinished business" and how the protest discourses of Swing were mobilized between I 83 I and I 833 respectively. The final sub-section asks whether the protests in this period represented something genuinely different from the events of late I 830, with particular reference to popular politics.

\section{DEFINING SWING}

Protest historians, whilst at variance over many matters, are in agreement regarding Swing's form(s) and purpose. In short, Swing assumed many forms - incendiarism, "mobbing", political demonstrations, attacks on migrant labourers, even food riots - but its "iconic" form nationally was the destruction of threshing machines. ${ }^{I 4}$ In many areas, including much of east Sussex, Surrey, and north-west Kent, threshing-machine-breaking, though, was conspicuous by its absence. Here, the protests that (locally) defined Swing were wage demonstrations and claims for more generous poor relief. Swing assumed whatever form it needed to from place to place whilst remaining true to a set of aims and claims that were universal. The common aim was to improve the living standards of the rural worker, whether through eliminating unemployment (attacking threshing machines), increasing wages or improving poor relief payments.

Whilst such standard of living protests were almost endemic in rural southern England in the post-Napoleonic period, they were usually either single cases or localized conflagrations. To be a Swing protest, the act had to occur in relation, or make reference, to other protest episodes. As social-movement theory posits, to be a protest movement, "activists" need to share common goals, to have some organizational frame, and to have a shared toolbox of protest methods. Through organization, in whatever

I4. Hobsbawm and Rudé, Captain Swing, p. 195. This "classic" interpretation has been reasserted in the latest study of the sociology of Swing. See Peter Jones, "Swing, Speenhamland and Rural Social Relations: the 'Moral Economy' of the English Crowd in the Nineteenth Century", Social History, 32 (2007), pp. 271-290, 275-276. 
form, goals are translated into actual protests. Moreover, the example of organization and protest in one area typically inspires organization and protest in other, often neighbouring, areas. Such an analysis chimes with Charles Tilly's delineation of the defining features of eighteenth and nineteenth-century social movements. To be a movement - as opposed to merely a grouping of discreet, random protest events - the protest episodes need to be undertaken by a set of activists who not only share similar goals and beliefs but also make claims to togetherness. ${ }^{\text {Is }}$ Thus, the waves of protest in I 830 that Andrew Charlesworth so elegantly mapped clearly show that protests in one locale often inspired, if not necessarily begat, protest in other parishes. ${ }^{16}$ Even apparently "isolated" protests in northern English counties often made explicit reference to protests in the south and east. Similar dynamics are also true of covert protests. The difference between an incendiary attack on a parsimonious farmer during Swing and a similar pre-Swing fire was that the Swing fire was in part inspired by other recent actions and occurred in a context of heightened anxiety.

Hobsbawm and Rudés claim that Swing protests were singularly devoid of organization has been shown to be untrue. Wherever the richness of the archive allows, it has been shown that protest groupings were highly organized, whether being based on pre-existing social alignments - criminal gangs, work gangs - or effected through the use of recruitment and "pressing". ${ }^{17}$ That Swing lacked an overarching, national organizational frame is of little importance because through shared community and customary codes remarkably similar local organizational forms occurred. As Peter Jones has recently iterated, the shared "moral economy" values that underpinned southern and eastern agrarian capitalism were also generative of broadly similar cultural, and hence organizational, forms. ${ }^{18}$

The shared goals and toolbox of protest forms, combined with evidence of organizational forms, diffusion, and protests in one locale inspiring protests at a distance, suggests that Swing was a protest movement. Or rather, Swing was an overarching protest movement that linked together, through shared aims, a series of essentially localized movements. What then marked the movement's beginning? As already noted, all of Swing's protest tools had been recently practised in south-east England. Attacks on threshing machines, either through incendiarism or machine-breaking, occurred with increasing frequency in the post-Napoleonic period. In May I 829, a threshing machine had been destroyed by an incendiary

I 5. Charles Tilly, Social Movements 1768-2004 (Boulder, CO, 2004), pp. I2-I4.

16. Charlesworth, Social Protest in a Rural Society.

17. Hobsbawm and Rudé, Captain Swing, pp. 56, 98; Griffin, “'There Was No Law to Punish That Offence"”; idem, "The Violent Captain Swing?", Past and Present (forthcoming).

I8. Jones, "Swing, Speenhamland and Rural Social Relations". 
fire at Lyminge in the centre of the area operated by the first Swing machine-breaking gang. Similarly, a wave of threshing-machine-breaking in the early months of 1829 in the area between Finchingfield and Toppesfield (Essex) provoked considerable alarm amongst both the local and national authorities. ${ }^{\text {I }}$

However, as John Archer has suggested, the Essex protests represented an intensification of protest activity rather than a coherent movement. $\mathrm{He}$ concluded that what marked Swing as something different from such isolated, if intensive protests, was the sustained nature of the east Kent protests and their subsequent diffusion beyond the immediate locality. ${ }^{20}$ Even the series of fires that occurred in the environs of Sevenoaks in the early to late summer of I 830 , whilst generative of much alarm, did not provoke protests elsewhere. They were localized and did not diffuse beyond the Kent-Surrey borders. Even William Cobbett's claim that the "occasion of the first riots was the importation of Irish labourers" during the early harvest on the Isle of Thanet is unhelpful, for these protests did not inspire actions elsewhere. ${ }^{21}$ In short, as Archer concluded, the only actions that can be meaningfully described as having kick-started a protest movement were the series of machine-breaking incidents in the Elham area of east Kent. However, it is important to note that the archive does not record that these first machine-breakers had any desire to see their actions replicated elsewhere. Instead, their actions, without their agency, provided the inspiration for the rapid diffusion of very similar protests underpinned by broadly similar claims.

Movements can do much besides, or even instead of, protesting. ${ }^{22}$ This matters little in relation to the start of Swing, for the reasons just identified, but has profound implications for thinking through how movements end. Indeed, if a low level of protest is not necessarily indicative of either declining social tensions or the collapse of a movement, then the absence of the iconic protest forms of machine-breaking and wages demonstrations would not necessarily be evidence of the death of Swing. Instead, a dip in protest activity could mask either local and/or regional variations, with some locales witnessing renewed protests after

\footnotetext{
19. Kent and Essex Mercury, I3 and 27 January; 3, I7, and 24 February; 3, I0, 17, and 24 March I 829; Janet Gyford, Men of Bad Character: The Witham Fires of the I 820 (Chelmsford, I991). 20. John Archer, Social Unrest and Popular Protest in England $1780-1840$ (Cambridge, 2000), pp. I6-17.

2 I. Hammond and Hammond, The Village Labourer, p. 179; Hobsbawm and Rudé, Captain Swing, pp. 97-98; John Rule and Roger Wells, "Crime, Protest and Radicalism", in idem, Crime, Protest and Popular Politics in Southern England, I740-I850 (Rio Grande, OH, 1997), pp. I-I 5 , IO.

22. Herbert Blumer, "Collective Behaviour", in Alfred McClung-Lee (ed.), Principles of Sociology (New York, 1969), pp. 65-120. Also see Nick Crossley, Making Sense of Social Movements (Buckingham, 2002), p. 5.
} 
earlier intensive activity. It could also represent a shift to a new phase and form of protest activity. As Nick Crossley has stated, "movements are always in movement, they are constantly changing". ${ }^{23}$

The concept of cycles of collective actions is also potentially of help. According to social-movement theorist Sidney Tarrow:

[W] hen we reconstruct cycles of protest from both public records and private memories, the peaks that leave indelible impressions in public consciousness are really only the high ground of broader swells of mobilization that rise and fall from the doldrums of compliance to waves of mobilization more gradually than popular memory recognizes. ${ }^{24}$

In relation to English rural protest, between the peaks of "movement" activity - the "Bread or Blood" riots of I8I6, the East Anglian protests of 1822 , Swing - we would expect a steady rise and a gradual fall before and after dramatic outbreaks. Any protest movement will be, so the model suggests, defined by the point at which the level of protest activity begins to increase and the point when protest activity again assumes a steady level.

These understandings have several implications for thinking through the life and death of protest movements. Firstly, whilst there might be a lead-in period to the existence of a fully fledged protest movement, this period can only be recognized retrospectively as laying the foundational conditions for the movement. Or, only once a movement has been identified can the prior upturn in protest be recognized as foundational as opposed to simply a temporary upturn in protest activity. Secondly, unlike the "pre"-movement phase, the period of "decline" between the peak of movement activity and the point at which the resort to protest assumes "normal" levels can be understood as part of the movement. Again, this point, or period, of transition can only be recognized retrospectively.

Charles Brockett's study of attempts to repress protest movements supports this "cycles" theory-derived analysis. Repression, of whatever kind, tends to produce one of two results. Either the movement is driven underground and is forced to adopt new protest stratagems, or movement activists refocus their efforts in achieving their collective goals. What, according to Brockett, rarely, if ever, occurs is that activists instantly become resigned to defeat and cease their protests. ${ }^{25}$

23. Ibid., p. 7 .

24. Sidney Tarrow, "Cycles of Collective Action: between Moments of Madness and the Repertoire of Contention", in Mark Traugott (ed.), Repertoires and Cycles of Collective Action (Durham, NC, 1995), pp. 89-1 I5, 96.

25. Charles Brockett, "A Protest-Cycle Resolution of the Repression/Popular-Protest Paradox", in Traugott, Repertoires and Cycles of Collective Action, pp. I I7-I44. 


\section{BEYOND THE TRIALS}

\section{Trajectories and practices}

If we are to apply "cycles" theory to the study of Swing, we necessarily need to both define a Swing incident and quantify the resort to protest. Both practices are fraught with epistemological danger. As noted, whilst it is possible to define the essential characteristics of a Swing incident, even by placing all events in context and testing to see whether it conforms to the Swing model, we cannot be certain that the protest was inspired by Swing. For instance, whilst a wages demonstration during the winter of I 830 can be meaningfully claimed as a Swing incident, we cannot be so certain in making like claims for an incendiary fire during, say, the summer of 1832 . However, all cases of incendiarism which occurred in the aftermath of the Swing trials occurred in the same context: the desire to see the gains of 1830 sustained.

Quantifying protest is similarly problematic. Riots, as Wells has suggested, may not have left an archival legacy for a variety of reasons. Magistrates may have been reluctant to inform the Home Office of a disturbance for fear of creating the impression that they were unable to control their district. Newspaper editors too may have decided not to report riots for fear of inspiring copycat protests. ${ }^{26}$ Similar dynamics also relate to covert protests. Indeed, the "lesser" quasi-political threat and danger to public order of an incendiary fire meant that such protests were even less likely to be reported to the Home Office. Another shared dynamic to the non-reportage of all protests was the geographies of newspaper publishing and reporting. In I 830 , large parts of rural England still did not have a dedicated local newspaper. Notwithstanding a few failed attempts, Surrey, for instance, remained newspaperless until the launch of the Guildford-based Surrey Advertiser in I 864. By contrast, the first successful newspaper in neighbouring Kent was launched in 1717. Some newspapers from beyond the county boundary did profess to cover news from neighbouring counties but in practice, this rarely assumed anything above a superficial level. Furthermore, self-styled "county" newspapers tended to report from a relatively narrow "news hinterland", only occasionally detailing events from far flung country parishes. ${ }^{27}$

Taking such complications into account, crude aggregate tallies of protest incidents can still give an indication of changing patterns of protest and levels of social tension. An analysis of extant copies of the

26. Roger Wells, "Counting Riots in Eighteenth-Century England", Bulletin of the Society for the Study of Labour History, 37 (1978), pp. 68-72, 69.

27. Carl Griffin, "Knowable Geographies? The Reporting of Incendiarism in the Eighteenthand Early Nineteenth-Century English Provincial Press", Journal of Historical Geography, 32 (2006), pp. 38-56, 43-46. 
Table I. Protest incidents, 25 December 1830 to end I 83 I

\begin{tabular}{|c|c|c|c|c|c|c|c|c|c|c|}
\hline & \multicolumn{2}{|c|}{ Hampshire } & \multicolumn{2}{|c|}{ Kent } & \multicolumn{2}{|c|}{ Surrey } & \multicolumn{2}{|c|}{ Sussex } & \multicolumn{2}{|c|}{ All counties } \\
\hline & $H \& R$ & Rev & $H \& R$ & Rev & $H \& R$ & Rev & $H \& R$ & Rev & $H \& R$ & Rev \\
\hline Incendiarism & 3 & 34 & 6 & 42 & 2 & 15 & 1 & 37 & 12 & 128 \\
\hline $\begin{array}{l}\text { Threshing- } \\
\text { machine-breaking }\end{array}$ & 0 & 0 & 6 & 4 & 0 & 0 & 0 & 0 & 6 & 4 \\
\hline $\begin{array}{l}\text { Strikes/wages/poor } \\
\text { relief assemblages }\end{array}$ & 0 & 3 & 2 & 12 & 0 & 0 & $0^{b}$ & 7 & 2 & 22 \\
\hline
\end{tabular}

${ }^{a}$ Excludes threshing machines destroyed by fire.

bexcludes the report of an "expected" labourers' meeting at Rye in October I83 I.

south-eastern provincial press, Home Office files, estate and personal correspondence, and judicial records, suggests the extent of reported incendiarism was underestimated by Hobsbawm and Rudé by a factor of nearly eleven to one (see Table I). Such figures are given even greater weight by the likelihood that there were increased pressures upon the provincial press not to report incendiary fires. In the aftermath of the events of I830, the County Fire Office informed Home Secretary Melbourne that: "We have endeavoured to discourage the frequent mention of these Acts in the Newspapers, thinking that such descriptions might set others on to produce similar devastations." 28

If we accept the patterns shown in Table I to be broadly representative of the trends of post-Special Commission protest, then there are several conclusions that can be made. Firstly, the resort to incendiarism in the last week of 1830 and throughout I83 I was both dramatically higher than in any pre-Swing year, including the crisis years of 1795 , I 800 , I 8 I 2, I 816 , and $1822 .{ }^{29}$ Secondly, notwithstanding the fact that no additional cases of machine-breaking have been identified in I $_{3}$ I - indeed two cases of threshing-machine-breaking "located" by Hobsbawm and Rudé did not actually occur $^{30}$ - the resort to open protest in I83 I was significantly higher than has hitherto been acknowledged.

28. Wells, "Social Protest, Class, Conflict and Consciousness", p. I 59 . We should not overemphasize this though, for, as Kevin Bawn has suggested, it was far less likely for an incendiary fire to go unreported in the I830s than the I790s; Kevin Bawn, "Social Protest, Popular Disturbances and Public Order in Dorset, I790-I 838 " (unpublished Ph.D. dissertation, Department of History, University of Reading, I984), pp. I09-I I0.

29. Carl Griffin, "As Lated Tongues Bespoke: Popular Protest in South-East England, 1790-1 840" (unpublished Ph.D. dissertation, University of Bristol, 2002), pp. 296-3 I I.

30. The two "phantom" cases supposedly occurred at Barham on 24 August and nearby Wingham two days later; Hobsbawm and Rudé, Captain Swing, p. 357. Further investigation revealed that no machine was destroyed at Barham on 24 August I 83 I, but a week later a stack of wheat was set on fire in revenge for the appreciation of a man alleged to have been active in the destruction of a threshing machine on 30 July belonging to the same farmer. At Wingham a 
Table 2. Protest incidents, $I 832$ and 1833

\begin{tabular}{|c|c|c|c|c|c|c|c|c|c|c|}
\hline & \multicolumn{2}{|c|}{ Hampshire } & \multicolumn{2}{|c|}{ Kent } & \multicolumn{2}{|c|}{ Surrey } & \multicolumn{2}{|c|}{ Sussex } & \multicolumn{2}{|c|}{ All counties } \\
\hline & 1832 & 1833 & 1832 & 1833 & 1832 & 1833 & 1832 & 1833 & 1832 & 1833 \\
\hline Incendiarism & 8 & 16 & 25 & 11 & 7 & 3 & 15 & 9 & 55 & 38 \\
\hline $\begin{array}{l}\text { Threshing- } \\
\text { machine-breaking }\end{array}$ & & & & 1 & & & & & & 1 \\
\hline $\begin{array}{l}\text { Strikes and wages/poor } \\
\text { relief assemblages }\end{array}$ & & & 2 & 1 & & & 4 & & 6 & 1 \\
\hline Other riots & & & 1 & 2 & & & 1 & 1 & 2 & 3 \\
\hline
\end{tabular}

Beyond I83 1 , the resort to incendiarism appears to have steadily declined. Only in Hampshire was this trend reversed, an increase in I 833 following a dramatic decline in I 832 (Table 2). The resort to Swing-type overt protests in I 832 and I 833 also showed a marked decline, exemplified by the fact that a single threshing machine was destroyed. Other open protests took the form of isolated labourers' strikes, attacks on migrant labourers, and occasional affrays provoked by attempts to arrest and prosecute protestors. Additionally, the archetypical Wealden protest activity in November I 830 of lobbying vestries and magistrates for higher wages and/or poor relief payments was also occasionally practised, most notably in Sussex. With the exception of the vicinity of Dover in the summer of 1833 , nowhere during 1832 and I 833 was there anything approaching a sustained, overt, local campaign. Not only was a threshing machine destroyed at Hougham in August I 833, but it was also reported that same month that there had been "[a] great deal of murmuring lately" over the recently adopted practice of mowing (as opposed to reaping) the wheat. Offending farmers were subjected to the "threatening insinuation" that their actions would have "dreadful consequences". One farmer at Langdon was duly targeted by incendiarists on 2 I August. ${ }^{3 \mathrm{I}}$

All such analyses hide a complex seasonality. Archer's analysis of the resort to incendiarism in Norfolk and Suffolk between I 8 is and I870 has

large number of the "peasantry" assembled, visiting the farmers to complain about their having allowed their wheat to be mowed rather than reaped and also expressing their "determination" that threshing machines would not be used again; Earl of Camden, Arlington Street, to Lord Melbourne, Home Office, 7 September, enclosing Wm Deedes, Sandling, to Camden, 4 September, N[ational]A[rchives], HO 52/13, fos 30-3 I; Kentish Gazette, 2 September I 3 I; Maidstone Journal, 30 August I83i; Kent Herald, i September I83 I.

31. The machine was destroyed at Hougham near Dover on I8 August I833 in the area in which the original gang of threshing-machine-breakers had operated; Kentish Observer, 22 August I833. For the activities of the Elham gang, see Griffin, “'There Was No Law to Punish That Offence", pp. I3 I-I63; idem., "Policy on the Hoof: Sir Robert Peel, Sir Edward Knatchbull and the Trial of the Elham Machine Breakers, I830", Rural History, is (2004), pp. I-22. 


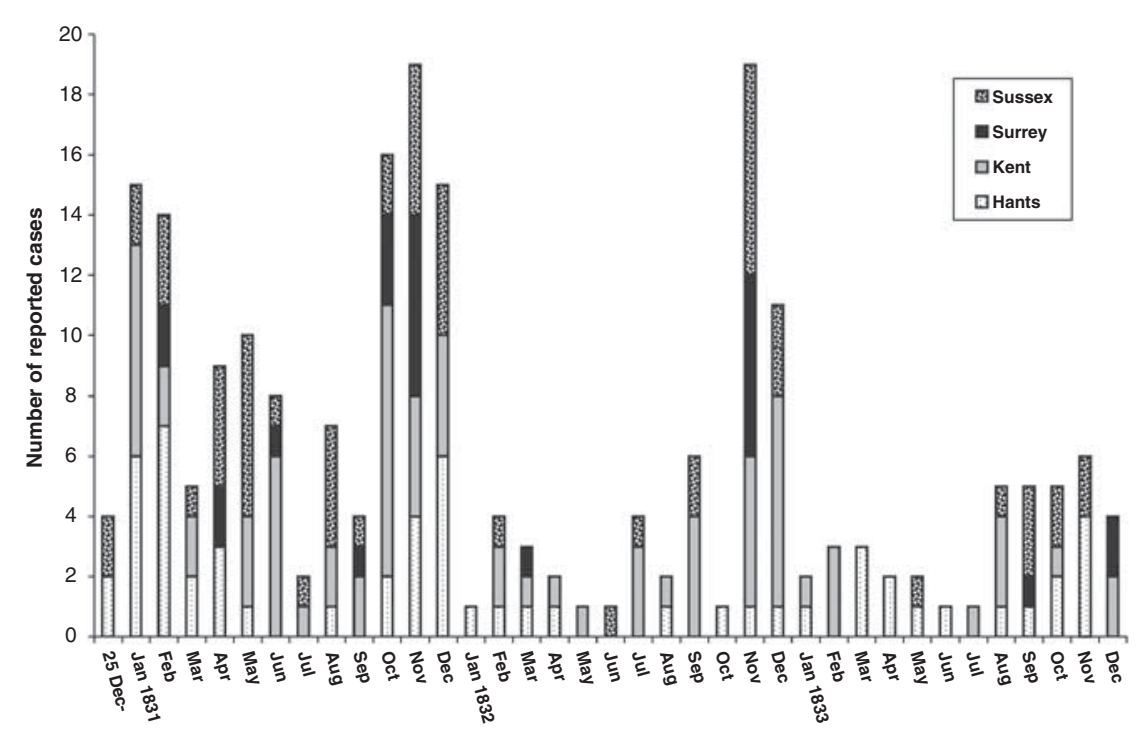

Figure 3. The monthly resort to incendiarism, 25 December 1830-1833.

demonstrated what appears to be a consistent, seasonal pattern. Incendiarism peaked in the winter months, declining dramatically in the New Year before rising again as the harvest ended. The post-Special Commission resort to incendiarism demonstrates a similar pattern (see Figure 3). Notwithstanding a far greater than would normally be expected wave of incendiarism in January and February I83I, the subsequent peaks occurred in the final three months of the year. Indeed, it was the dramatic nature of the post-harvest peaks in I 83 I and I 832 that is arguably of greatest import. Not only did these peaks broadly - mirror the expected pre-Swing trend, but they also reflected the months at which Swing was at its most intense. ${ }^{32}$ That this extensive resort to arson in the winters of I 83 I and I 832 might simply be a reflection of the intensification of hardships for labouring families in the post-harvest period is refuted by the far greater intensity of protests than would normally be expected. Moreover, neither winter was particularly severe.

\section{The response to repression}

On the morning of Sunday i4 November I 830, Mr Franks's Albury mill was set on fire. Several gun shots were also fired through his bedroom 
window. Franks, according to the son of the Attorney General, had become "odious to the people" in his capacity as the Albury overseer. ${ }^{33}$ Five days later, James Warner, a 30-year-old labourer, was committed to stand trial at the Surrey Assizes as the alleged culprit. In due course, Warner was found guilty and sentenced to be hanged. According to Justice Bosaquet, it was "impossible that mercy could be extended to him in this world", thereby prejudicing the chances of any appeal. News of the conviction immediately provoked "a strong sensation" in the locality. As if this "sensation" was not a strong enough deterrent, there were calls for the execution to take place on Shere Heath or another convenient site close to the scene of the fire. ${ }^{34}$

Not only was the place of execution a source of contention but so too was the sentence. On the night of 6 January I83 I, shots were fired through the bedroom windows of the Master of Albury workhouse and a threatening letter was fixed to a post near Albury Park, the residence of committing magistrate Drummond. Reports of the exact wording of the letter vary, but the sentiments were clear. "We fired the mill; starving and firing shall go together" reported the Kentish Gazette. The County Chronicle, four days later, claimed it read "It was me who fired the Mill starve and fire go together". Another threatening letter, found near the Guildford workhouse, went further: "If Wrner is mured Franks Dromans [Drummond] an Smallpiece [a "witness"] shal dye i culd clear im [...] you fals swaring villing". ${ }^{35}$ Notwithstanding these threats, at a little before 9 o'clock on the morning of io January i 83 I, at Horsemonger Lane Gaol, Southwark, Warner was launched into eternity. ${ }^{36}$

Warner was the sole Surrey Swing activist to be executed or transported to New South Wales or Van Diemen's Land. The judicial toll taken by the other south-eastern courts was, cumulatively, more severe (see Table 3). In Sussex, I7 men were transported for their involvement in a variety of

33. The Times, i6 November; Attorney General, Court of King's Bench to Peel, is November I 830 , enclosing a letter from his son, I4 November I 830 , NA, HO 52/10, fos 194-196.

34. Indictment of James Warner, Surrey Winter Assizes, NA, ASSI 94/2070; Morning Chronicle, 3 January I831; G. Holme-Summers, Hatchlands, Guildford, to Melbourne, 4 January i 83 I, enclosing letter from G.W. Onslow, Guildford, n.d. (late December I 830 or early January i 83 I), NA, HO 52/ I2, fos 367-369. As it stood, the last scene of crime hanging to occur in England was at Kenn (Somerset) in the summer of I830; Steve Poole, "A Lasting and Salutary Warning': Incendiarism, Rural Order And England's Last Scene of Crime Execution”, Rural History, i9 (2008), pp. 163-177.

35. George Walton Onslow, Chairman of the Guildford Bench to Melbourne, 8 January i 83 I, NA, HO 52/I2, fos 363-364; Kentish Gazette, I 4 January i 83 I; County Chronicle, I 8 January I831; The Kentish Gazette (I4 January I831) gave a slightly different version: "Warren is murdered; Franks, Drummond and Smallpiece shall die; I could clear him at the place, you false swearing villains!”.

36. G. Holme-Summers to Melbourne, 7 January i 83 I, NA, HO 52/I2, fos 370-37I; County Chronicle, i 8 January I 83 I. 
Table 3. Number of "Swing" activists transported and executed, I $830-$ early I 83 I

\begin{tabular}{lcccc}
\hline & Hampshire & Kent & Surrey & Sussex \\
\hline Transported & 117 & $25^{*}$ & & 17 \\
Sentenced to death & 101 & 5 & 1 & 3 \\
Executed & 3 & 4 & 1 & 1 \\
\hline
\end{tabular}

Source: Hobsbawm and Rudé, Captain Swing, pp. 308-309.

*Includes those sentenced at the Romney Marsh Epiphany Sessions I 832 for destroying threshing machines on Is August I83 I.

different crowd actions. In Kent, 25 individuals, including one woman for incendiarism, were transported. The toll in Special Commission-tried Hampshire was far greater, even though protests had been no more intense or widespread than in Kent and Sussex. Here II7 men were transported, the vast majority of whom had initially been condemned to death but subsequently had their sentences transmuted. ${ }^{37}$

Crude numbers do little justice to the sense of loss engendered in the communities from which these individuals were removed. Nor do numbers help us understand the popular reaction to executions and transportations. Indeed, the figures quoted by Hobsbawm and Rudé, whilst correct, tend to hide as much as they reveal. In Hampshire, out of the three men executed, two, Henry Cook for "robbery" at Northington and James Thomas Cooper for rioting at Fordingbridge, were tried by the Special Commission. Both were executed at Winchester on is January I 83 I. $^{38}$ The third man, John Sansom, was convicted at the Hampshire Lent Assizes in I 83 I for a pre-Swing protest: setting fire to a wheat rick at Hound on 9 December i828. Sansom was executed shortly after his trial. ${ }^{39}$ Three labourers were executed for incendiarism at the Kent Winter Assizes I 830: brothers William and Henry Packman being found guilty of setting fire to farmer Wraight's property at Blean on 2I November, and John Dyke for firing farmer Stokes's property at Bearsted on Io November. All three were executed on Christmas Eve in front of "an immense concourse of spectators" on Penenden Heath..$^{40}$ Edmund Bushby was the sole Sussex Swing activist to be executed that winter. He met his fate

37. Hobsbawm and Rudé, Captain Swing, pp. 308-309.

38. Hampshire Chronicle, 27 December I 830; Hobsbawm and Rudé, Captain Swing, p. 26r.

39. The Times, I and 3 March I83I; Jackson's Oxford Journal, I2 March I831; Hampshire Telegraph, I I April I83 I. Sansom was initially arrested in connection with a further fire on farmer Buckland's property at Hound on s September 1830; Southampton Mercury, I I September i 830 .

40. Maidstone Journal, 28 December 1830 ; The Times, 29 and 30 December 1830. 
upon the Horsham gallows on New Year's Day i 83 I for firing threshing machine user Olliver's wheat stack on 28 November $1830 .{ }^{4 \mathrm{I}}$

The intention of the Special Commission, according to a briefing sent to the Hampshire magistrates by the Attorney General, was to demonstrate that "the ends of public justice" had been "sufficiently answered" by convicting and punishing "a certain number" of the offenders "in the different mobs". It was imperative, he went on, that all those so prosecuted must be convicted. Acquittals were "very impolitic" in such circumstances as they tended to produce "a bad effect". ${ }^{42}$ However, according to Revd Dallas of Wonston in the Dever Valley, this policy had been carried out too dogmatically. Having "bared the sword of justice with manly firmness, and [...] a solemn Christian spirit", the Commission had initially evoked "in a most wholesome manner" the "desired effect" amongst his parishioners. His parishioners, most of of whom had been active participants in local Swing groups, had "learnt to fear for the consequences", eagerly waiting and speculating upon the outcome of the trials thus helping to deepen the impression of fear and "prolong[ing] the conviction of error". However, the penalty of death had not been seriously discussed. Thus, when the sentences were announced, the effect was dramatic. That six men were to be condemned altered the mood from the "wholesome conviction" of error to "bitterness". ${ }^{43}$ Not only were the people of Sutton Scotney now "easy dupes of the vile agitators" but also "likely" to resist the "execution of the law". Executing the six men who were not found guilty of arson or "acts of malicious personal violence" - for which death was a fitting penalty - would tend to produce "a rankling resentment which [...] will be widely felt". ${ }^{44}$ As Robert Mason, writing to Revd Joliffe, his prosecutor at the Special Commission, from his prison cell in Winchester Gaol whilst awaiting transportation to Australia, exclaimed: "I did not know that what I did was a 'fault' much less a 'FELONY'", 45

And yet, with the exception of events at Albury, the combination of the conviction of such men for seemingly minor acts and the judicial murder of incendiarists did not prompt a resort to protest. This may have been

41. Sussex Advertiser, 6 December I830 and 3 January I831; Brighton Gazette, 23 December I 830 .

42. Instructions from the Attorney General to County Magistrates relating to prosecution of cases arising from the riots, no date (but December I830), H[ampshire] C[ounty] R[ecord] $\mathrm{O}\left[\right.$ ffice], ${ }_{22} \mathrm{M}_{95} / \mathrm{F}_{2} / \mathrm{I} \mathrm{I} / 2$.

43. After sustained petitioning, John Gilmore (Andover), Robert Holdaway (Headley), Henry Eldridge (Fordingbridge), and James Annals (Barton Stacey) were all reprieved in mid January I 83 I.

44. Revd A.R.C. Dallas, Wonston Rectory, to Melbourne, 8 January i 83 I, NA, HO 52/I3, fos II 3 -IIS.

45. Letter from Robert Mason, County Gaol to Revd J. Joliffe, Barton Stacey, 27 January I 83 I (in Lord Northbrook's papers), HCRO, ${ }_{92} \mathrm{M}_{95} / \mathrm{F}_{2} / 8 / 5$. 
due to the terror affected by the law. It may also have been a function of the fact that many towns in the south-east still hosted garrisons of troops dispatched to keep order during late 1830 . For instance, the environs of Sittingbourne, the area in which Swing was first manifest in its overt form beyond its initial east Kent centres, remained entirely protest-free in the early months of I 83 I. Revd Poore, a local magistrate, wrote to Melbourne on 2 I March to proclaim that all was now "quiet" and that the troops were no longer required. ${ }^{46}$

Instead, initial recriminations appear to have taken a more ruminative form. For instance, a relative of Bushby was heard to leave the scene of his execution making "threats of vengeance". ${ }^{47}$ What evidence of vengeance there is tends towards suggestion rather than offering any explicit connection. Farmer Hayward at Whitstable received three threatening letters in early January warning that unless he brought his threshing machine "forward" his premises would be fired. On I7 January, the threats were made good. Intriguingly, even though the fire occurred well within the news hinterland of the several Canterbury papers, it was left to The Times to report the fire. ${ }^{4}$ Hayward's farm was located only four miles from Wraight's Denstroud farm for which incendiary fire the brothers Packman hanged. Whether there was a direct link is unclear, but it seems likely that the execution of the brothers would have further inflamed already perilous social relations in the area.

We must not forget that judicial repression, both in the issuing of punitive sentences and the considerable pressure placed upon fellow workers to inform against their comrades and neighbours, took a heavy toll on plebeian community cohesion. Whilst this is not the place to offer a detailed analysis of the changing levels of intra-community violence in the post-trial period, the following case suggests deepening tensions. Labourer Bartholomew was subjected to a bitter verbal tirade and an even more violent assault at the William IV pub at Bridge, near Elham, on being accused of having "split against the Party". His actions were supposedly responsible for Henry Hulkes having been sentenced to seven years' transportation for breaking farmer Friday's threshing machine at neighbouring Bekesbourne. Those guilty of the assault even offered a gallon of beer to anyone would lynch Bartholomew. ${ }^{49}$

There was, however, a definite link between the targets of these postrepression months and the targets of the winter of 1830 . An incendiary

46. Revd Poore, Murston, to Melbourne, 21 March i83i, NA, HO 52/13, fo. I7.

47. Sussex Advertiser, 3 I January I 83 I.

48. Four men lost their lives whilst extinguishing the flames, prompting the offer of a huge $£_{1}, 000$ reward for information leading to the conviction of the arsonist; The Times, i9 January I83 I.

49. The Times, 29 November 1830; depositions of labourer Bartholomew and innkeeper Moors, io December i 830, CKS Q/SBe/122/. 
letter sent to the Greenwich overseer threatened that three men were coming from "Barkshire" to destroy his machines, set fire to his straw, and poison all his horses..$^{\circ}$ At Amberley, near Arundel, a special constable, presumably sworn in at the height of Swing, was attacked on Boxing Day. ${ }^{\mathrm{I}}$ Elsewhere, the flurry of incendiary fires and threatening letters were disproportionately targeted at poor law officials. This was not in itself unusual but novel in its intensity. ${ }^{52}$ The recurring motif of the hatred of machinery and the use of the monosyllable "Swing" was also novel in relation to previous winters. Farmer Humphrey at Donnington, near Chichester, received a "Swing" letter threatening to burn his premises if he used his threshing machine. Farmer Godwin at Fareham was less fortunate. The incendiary threats detailed in a series of "Swing" letters were acted upon at 4 am on 3 February, even though he had long since stopped using his threshing machine. ${ }^{53}$

There is some sense in which the tenor of such attacks represented something defiantly post-repression. Both Donnington and Fareham were in areas where threshing-machine-breaking the previous November had led to successful prosecutions at the Sussex Winter Assizes and Hampshire Special Commission. ${ }^{54}$ If the continued existence, if not necessarily use, of threshing machines remained a source of local contention, then the resort to covert rather than overt protests suggests either an inability to raise machine-breaking groups or a general fear/belief that to openly protest would lead to severe sanctions. This sense is reinforced by a petition drafted and signed by the working population of Bilsington, on the fringes of Romney Marsh, calling for threshing machines to be banned.5s Again, only the previous winter Bilsington had witnessed an unusually violent contretemps between a mobile Swing gang and a force of special constables which led to the successful prosecutions of five men for riotous assembly. ${ }^{.6}$

50. Kent Herald, I 3 January I 83 I; Rochester Gazette, i 8 January i 83 I.

5 I. Examinations of John Pennicott, tailor, William Serle, labourer, and Robert Braby, cordwainer; all 27 December I830, West Sussex County Record Office, QR/W/758, fos 269-272. 52. Kent Herald, I 3 January I83 I (Greenwich); Sussex Advertiser, 22 January I8 3 I (East Grinstead); J. Moneypenny, Hadlow to Melbourne, s February, NA, HO 52/I3, fos I3-I4 (Hadlow: assistant overseer); Reading Mercury, 7 February I 83 I (Burghclere).

53. Sussex Advertiser, 31 January I83 I; Rochester Gazette, I February I83 I; Hampshire Telegraph, 7 February I831; Berkshire Chronicle, I2 February I831.

54. Hampshire Telegraph, 27 December I 830.

55. Kentish Gazette, I March I 83 I.

56. W.R. Cosway, Sandgate, to Peel, i7 November i 830 , and enclosure, NA, HO 52/8, fos 2-7; The Times, I9 November and 27 I830; Kentish Gazette, 19 and 23 November I 830; rough list of sentences given to thirty machine breakers, n.d. (but 25 or 26 November I 830 ), rough assessment of destroyed machines, and list of twelve prisoners' sentences, n.d. (but 25 or 26 November 1830), Gaol Calendar, East Kent Special Sessions November i830, with notes of verdicts and sentences, 25 November I830; CKS Q/Sbe I21/14, Is and 16; Kent Herald, 2 December I830. 
Similarly, the tone of an incident in east Kent was suggestive of a new defiantly post-repression modus operandi. On New Year's Day, a group of between "I4 and I 8 Herne paupers" marched to Canterbury to lodge a complaint with the magistrates against Mr Thorpe, the assistant overseer. The magistrates listened to their complaints and duly ordered the parish officers to increase the men's pay to I $3 \mathrm{~s} 6 \mathrm{~d}$ a week. Initially, the officers refused to assent to the order, for, so they claimed, the parish could not afford such a sum. The Bench retorted that whether the parish could afford the payment was not important, it was the responsibility of the vestry to find the money. ${ }^{57}$ Magistrates, so such a public performance of paternalism was intended to infer, were the labourers' friends. If called upon to right injustice, they would set right all wrongs. But the complicity of many magistrates in the Government's schema of bloody repression engendered a deep-seated mistrust amongst many rural workers, something evidenced in protests directed at individual magistrates in January I $83 \mathrm{I}^{58^{\circ}}$

The popular response to wage cuts in the early months of $183 \mathrm{I}$ also represented a post-repression phenomena. Swing's many successes were hard won, something felt particularly in areas where the various trials had taken individuals from their families and friends. Any attempts by farmers and vestrymen to renege on earlier commitments were therefore a tacit admission that the deal forged during the autumn and winter of 1830 had, at least partially, collapsed. The potential danger of lowering wages was well understood by Wealden magistrate, Sir Charles Blunt. He reported in disapproving tones to the I83 I East Sussex Epiphany Quarter Sessions that several parishes were again lowering wages. At Billingshurst, so the Kentish Gazette reported, the farmers, in concert, had reduced the wages of married men to Ios a week and those of single men to 6s. The Sussex press however maintained a silence on such matters. ${ }^{59}$

The response of labourers to wage cuts was twofold: covert terrorism and open agitation. The former is necessarily harder to read for the simple fact that the specific motivations of incendiarists and maimers were infrequently recorded. A threatening letter sent to a Morden farmer offered explicit analysis: "Sir I will burn your place down to the Gound if you don't rise the men money and let the men keep a pig and do away with your hay devil". The writer, labourer John Longhurst, was subsequently found guilty of the act and sentenced to seven years transportation at the Surrey Lent Assizes. ${ }^{60}$ At Ockley two incendiary fires on

57. Kent and Essex Mercury, 4 January I $83 \mathrm{I}$.

58. County Chronicle, i 8 January I 83 I (Albury and Shere); Kent Herald, 20 January I83 I (Dover) Kentish Gazette, 2I January i83 I (Northfleet); Sussex Advertiser, 3 I January I83 I (East Grinstead). 59. Maidstone Journal, I 8 January I83 I; Kentish Gazette, I February i 83 I.

60. Indictment of John Longhurst, labourer, and Calendar, Surrey Lent Assizes i 83 I, NA ASSI 94/2 100. Longhurst was found guilty and sentenced to seven years' transportation. 
2 I April were considered evidence that a "plan of operations" regarding a "disposition" to strike had begun, thereby combining open and covert protests in the classic Swing modus operandi. Fears of a renewal of I 830 were quite understandable, for plans were afoot in Horsham and Dorking to "create tumult like on io Nov last year". Handbills were posted in the towns and the surrounding countryside calling for a mass assemblage on I 3 April to harass the magistrates during their examination of the overseers' accounts. Such was the panic generated, that the Bench informed the Home Office that they were unable to rely upon special constables to put down affrays. ${ }^{6 r}$

The Horsham events were not unique. In late January, labourers in the vicinity of Wonston struck their work for higher wages, thereby suggesting that the Revd Dallas's analysis of judicial policy was unerringly accurate. $^{62}$ Similarly, at the east Sussex Swing centre of Battle, a plan was afoot in late March to affect a rise in wages. "Many parishes in this part", so local grandee Sir Godfrey Webster informed the Home Office, "are afflicted and communicate with each other by means of Delegates, and are determined upon a compulsory increase of wage[s]". ${ }^{63}$

\section{Unfinished business?}

The response to wage cuts can also be interpreted not as the start of something defiantly post-Swing, the massive promise of Swing quickly giving way to a battle of attrition between labourers and farmers, but instead as an attempt to reinforce Swing's gains. ${ }^{64}$ If the events around Horsham and Battle were suggestive of a desire amongst labourers to protect living wages, events in the late spring and summer of I 83 I were proof positive. Initially, this resistance to the "lowness of wages" took the form of "open" complaints in the country parishes in the vicinity of Rochester, and open threats in the parishes between Sittingbourne and Faversham that "burnings and nocturnal depredations" would be revived. Both were, importantly, areas central to the early diffusion of Swing beyond its initial local centres.

Meanwhile at Aldington, on the fringe of the area in which the Elham machine-breakers operated, the labourers were reported to be holding secretive nightly meetings - a move uncannily reminiscent of the start of Swing in east Sussex at Brede. ${ }^{65}$ The first evidence that threats and plans

6I. D. Stedman, Horsham, to Melbourne, 8 April, NA, HO 52/I s, fos 6-8; anon., no location, to 'My Dear John', 2 I April i83 I, ESCRO HIC 980.

62. Hampshire Telegraph, 3 I March I 83 I.

63. Sir Godfrey Webster, Battle Abbey, to Melbourne, 28 March i 83 I, HA, HO 52/ i 5 , fo. I 5.

64. Archer, By a Flash and a Scare, pp. 250-257.

65. Rochester Gazette, 2I June I83 I; Maidstone Journal, 21 June I83 I; Kent Herald, 7 July I $83 \mathrm{I}$. 
were put into operation came not from Kent, though, but from the parishes to the south and east of Chichester, a major centre of ferment the previous November. In the final week of July, prompted by an influx of migrant "West Countrymen" labourers seeking employ in the early harvest, "great numbers" of men combined at Oving and Aldingbourne to "fix" the price of harvest labour with the farmers. At nearby Siddlesham, fifty labourers met on Sunday 24 July for the same purpose. On attempting to carry their plan into operation at neighbouring Selsey, they were resisted by the local labourers who refused to join them. The next day at nearby West Wittering a group of "strangers" seeking harvest work were also "roughly handled". ${ }^{6}$.

This model of localized, but intensive, open protest was also adopted in other centres of Swing activity. The earlier threats in the Swale parishes were made good on 2 August. Three individual, but interconnected, groups traversed an area between Newington-next-Sittingbourne and the Isle of Grain in a concerted attempt to "compel an increase of farming mens wages", and prevent the farmers from employing migrant harvest labourers. Three members of the Isle of Grain group were apprehended and later committed to trial by the Chatham Bench. On 4 August another "rising" occurred, this time in the vicinity of Sittingbourne. Again, the magistrates were quick to act, lodging "several" members of the group in Canterbury gaol. Notwithstanding the fact that the Revd Poore wrote to Melbourne the following day expressing his satisfaction that the "mobbings" had been "suppressed", a detachment of dragoons arrived at Sittingbourne on 6 August. ${ }^{67}$ Evidently, this planned - and intensive resort to open protest was too uncannily similar to the events of the previous winter for the government not to take action.

The other major centre of protest that summer was the area between Canterbury, Dover and Sandwich, broadly contiguous with part of the area operated by the Elham and Ash machine-breaking gangs of i 830 . Evidence precludes any accurate assessment of the actual individuals involved, or even whether the same individuals were responsible for the several acts of protest committed. However, it was clear that a spirit of open plebeian resistance permeated large parts of the area that had been responsible for the start of Swing the previous summer.

The first incident occurred at Barham on 30 July when a small group of men destroyed Mr Harvey's threshing machine. Harvey, instructively, had also been targeted by machine-breakers on 23 October 1830 . This was not so much unfinished business as a return to the previous winter's agenda. ${ }^{68}$

66. Brighton Gazette, 28 July i 83 I.

67. Revd Poore, Murston, 5 and 6 August i 83 I, J. Bradley, Sittingbourne, 6 August I 83 I, both to Melbourne, NA, HO 52/I 3 fos $87-88,72-74$ a and $70-7 \mathrm{I}$.

68. Kent Herald, 4 August and 22 September I831; Kentish Gazette, 2 September I 83 I. 


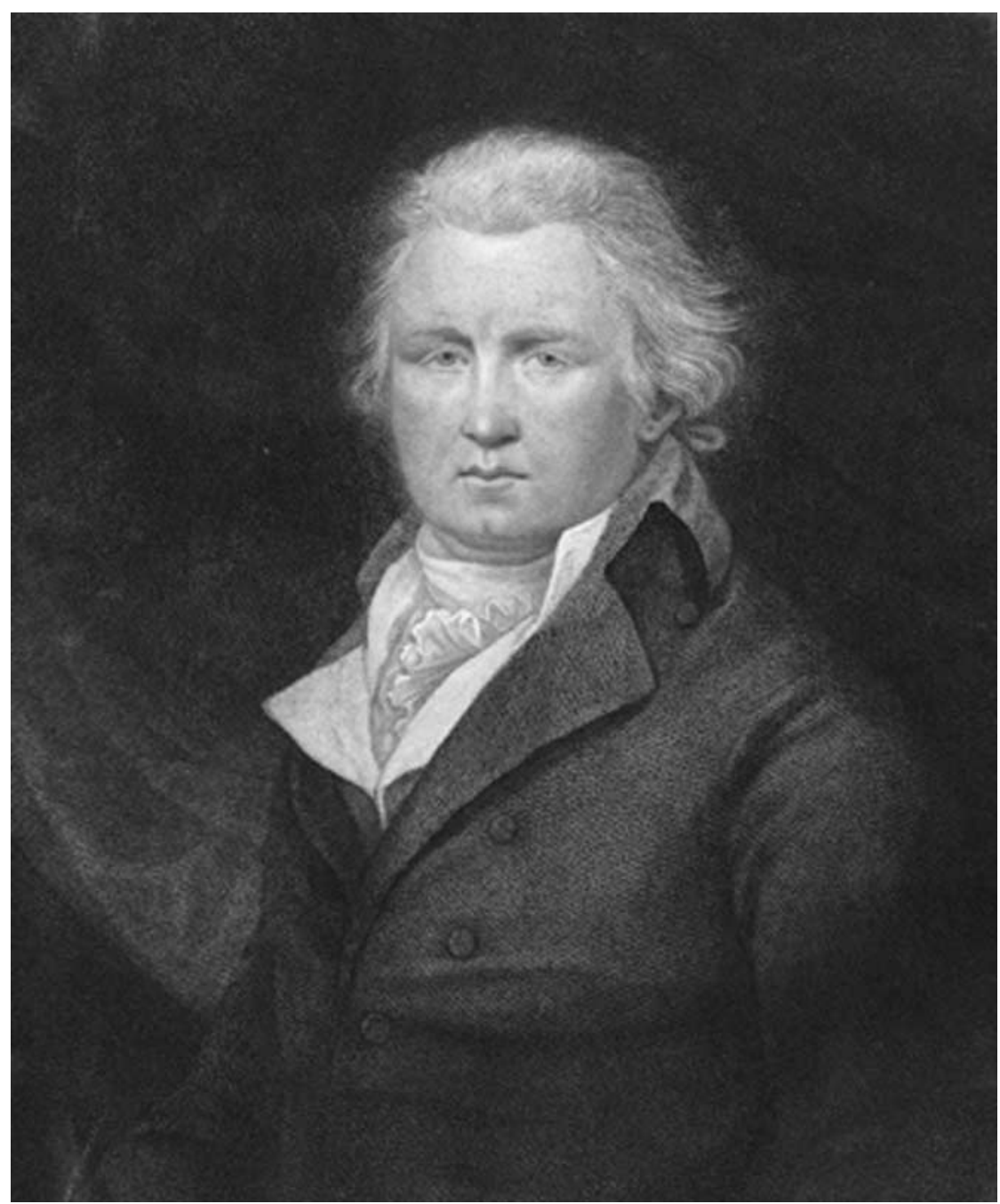

Figure 4. William Cobbett.

Hulton Archive/Getty Images. Used with permission.

Five days later another machine was destroyed at Ripple near Deal. According to the Deal bench: "The Peasantry openly state that it has arisen from the conviction of Government that they cannot punish Machine breaking by law and that consequently orders are sent out to New South Wales to release and send home those who have been transported for that offence." Moreover, there was supposed to be "a bad spirit abroad", something allegedly exacerbated by the popularity of Cobbett's papers in local pubs. Further evidence of this tendency to resist was 
provided by reports that the mown - as opposed to the more labour intensive sickle-cut - wheat of a farmer in a neighbouring parish to Ripple had been scattered over a field, littered across the road and thrown into a pond. A wheat stack in a village close to Canterbury was also set on fire the same evening. On 9 August the Deal Bench, a little prematurely, again wrote to Melbourne. A blacksmith, a farm servant and six day labourers had been taken up for the offence. This was likely, so thought the bench, to "check" the bad spirit. ${ }^{69}$

It might have had some effect at Ripple but it did nothing to stop the mass destruction of scythes by a "large party of fellows", comprised of "many bricklayers" but few field labourers, at Maxton, near Dover. Farmer Rutley, it was widely known, was planning to mow his wheat. The same complaint, combined with the now seasonal vehement opposition to the employment of Irish labourers, also provoked a "turn out" of the labourers at Bridge. Here, the striking labourers went to farmer Brice's harvest fields, seized the scythes and destroyed them, prompting Brice to "come to terms" with the local men. The provincial press probably woefully underreported such tensions. The Kentish Gazette rather obtusely admitted in the aftermath of the Bridge strike - which they did not report - that they had received "reports" of disputes between the indigent labour force and migrant Irish workers. The latter group were apparently willing to work "for whatever wages they received", and were happy to use scythes as opposed to the natives' traditional sickle. Further attacks occurred at Wingham, and at Hougham where Irish workers were assaulted, stripped, robbed, and then dragged through a horse pond and had their sickles broken. ${ }^{70}$

The protests at the latter place took a more Swing-like form. A "considerable" number of the "peasantry" assembled, pressing others to join them as they paraded the district complaining that the farmers had mown their wheat. They also expressed their "determination" not to allow threshing machines to be used again. ${ }^{71}$ Plebeian solidarity was also central to what were probably the last dramatic acts of protest to occur in the area. The arrest of Bridge labourer John Graves in late August, on suspicion of destroying Harvey's threshing machine at Barham, provoked prolonged recriminations. Farmer Harvey of Barham was again targeted, his situation made yet worse by his hiring of labourers, presumably migrants, to mow his wheat, and by the involvement of his landlord, local magistrate General Mulcaster, in Graves's committal. On the night of 3 I August a "very large” stack of Harvey's wheat was set on fire. Before the

69. Deal Bench to Melbourne, 5 and 9 August $18_{3}$ I, NA, HO 52/1 3 , fos $75-76$.

70. Kentish Gazette, 9 and I2 August I83 I; Kent and Essex Mercury, 9 August I83 I; Maidstone Journal, I6 August I83i; Kent Herald, i8 August I83 I.

71. Maidstone Journal, 30 August I831; Kent Herald, I September I831. 
Canterbury fire engines arrived, the fire had taken hold. The situation was exacerbated by the refusal of the local labourers to assist in extinguishing the flames. Open protest begat covert protest which, in turn, begat further open protest. According to local magistrate William Deedes, the "local constables dare not act". The correspondent of The Times went further: a "continued state of warfare [exists] between employers and labourers". ${ }^{2}$ But here, with the exception of a case of incendiarism against Farmer Every at Singledge, and a case of animal maiming against another farmer in the vicinity of Singledge, this intensive wave of protest ended. ${ }^{73}$

The only other locale in the south-east to experience systematic open protests was the edge of Romney Marsh, where, as we have seen, labourers had already petitioned against the use of threshing machines (Bilsington) and had been holding secret nightly meetings (Aldington). It was perhaps not too surprising therefore that the use of threshing machines on the Marsh would provoke considerable anger. On the night of is August, notwithstanding the fact that in anticipation of an attack a party of dragoons had been stationed at Romney "for some days", two threshing machines were destroyed: one at Bonnington and one at Burmarsh. A party of twenty-five to thirty individuals, many of whom were boys, came down "from the Hills" and entered the Marsh over the bridges. According to magistrate Stringer, the Marsh was free from Swing the previous year because he and his fellow magistrates had been quick to swear in special constables. One assumes that the continued existence of threshing machines especially rankled with neighbouring communities who had paid a heavy price for their involvement in the autumn and winter of 1830 . Thus, they descended the hills and sought to right a local anomaly. Their actions were given further popular legitimacy by the widespread belief, as at Ripple, that it was no offence to break threshing machines. ${ }^{74}$ These were necessarily selfcontained protests, acts of unfinished business.

Here acts of organized protest, with some notable exceptions, ended. The descent by 100 labourers on the vestry at Billingshurst on 7 November demanding wages of $2 s$ a day for married men and child allowances of $2 s$ a week per every child beyond the second in the family, harked back to the (temporary) success of such strategies a year previously. That Swing's gains had been short-lived was clearly the motivation, for, so it was reported,

72. Earl of Camden, Arlington Street, to Melbourne, 7 September I83 I, enclosing letter from William Deedes, Sandling, to Camden, 4 September I 83 I, NA, HO 52/I 3 , fos $301-302$; Kentish Gazette, 2 September I83 I; The Times, Io September I831.

73. Kentish Gazette, 20 September I 83 I.

74. W. Stringer, New Romney/Newhall, Dymchurch, I6, I7, I 8 and 20 August I 83 I; Camden, The Wilderness, to Melbourne, 28 August 183 I, enclosing a letter Deedes, Sandling to Camden, n.d., NA, HO 52/13, fos 89-90, 91-92, 93-103, 79-80 and 66-69; Kentish Gazette, 23 August I 83 I. 
many of the 99 men out of work and employed by Billingshurst parish existed solely on a diet of potatoes and lodged in outhouses. The other notable exception occurred two days later at perennially disturbed Rye - scene of a "fracas" that April - where the millers, farmers, and merchants were summoned to the "annual meeting" of the labourers. The meeting had been advertised in the adjacent parishes by a series of "bills". Fifty soldiers were duly despatched, whilst the local farmers tried to dissuade their labourers from attending. By noon, several men were seen lurking about the site of the proposed meeting carrying short bludgeons and sticks. Here reports differ. The Kent press stated that a "serious riot" had taken place, whilst Mayor Lamb, a normally diligent Home Office correspondent, made no such report.75

Whilst the swift repression of these intensive, if localized, protests eliminated any fear that the rural poor would again rise en masse, the high level of covert protest did raise concerns regarding the social stability of the countryside. In the face of hostility from the authorities and the abiding presence of military detachments in several areas, those seeking redress and psychological release through protest turned to incendiarism. Indeed, fireraising in the final three months of $183 \mathrm{I}$ assumed an 1830 -like level of intensity that some feared would inevitably lead to renewed overt protests. As Sir James Grey, informing Melbourne of an incendiary fire at Eastry, exclaimed: "the Horrid scenes of last year have returned". ${ }^{76}$ Whilst the fires assumed a Swing-like intensity, they did not represent unfinished business. Instead, they embodied, as Archer has suggested, "a deep-seated anger”. This had the appearance of, as Cobbett suggested, an attritional "rural war". ${ }^{77}$

It is telling that the Eastry fire followed, it later transpired, a strike of local labourers who "debated whether a fire was not likely to frighten the farmers into an advance of wages" ${ }^{8}$ There is some evidence that this strategy could succeed. According to the Foulmere (Cambridgeshire) overseer, the morning after a fire at nearby Guilden Morden, the vestry assembled and debated whether to increase the labourers' wages. The Foulmere overseer, being present at the Morden meeting, "remonstrated with them upon the impolicy of doing it then, as it would be a bonus for such wickedness". ${ }^{79}$

The trial, and subsequent execution, of young labourers for incendiarism at Guestling (Thomas Bufford, executed at Horsham on New Year's Eve

75. Kent Herald, 6 May, Io and 24 November I83 I; Mayor Lamb, Rye, to Melbourne, 7 and 9 November I 83 I, NA, HO 52/I 5 , fos 22-23 and 39-40.

76. Sir James Grey, Ramsgate to Melbourne, i7 November I83 I, NA, HO 52/I3, fos 32-38.

77. Archer, Social Unrest and Popular Protest, p. $2 \mathrm{I}$.

78. The Times, 24 December I831.

79. Report from His Majesty's Commissioners for Inquiring into the Administration and Practical Operation of the Poor Laws, I834, British Parliamentary Papers, Appendix B.I, I0, 3 , cited in Jones, "Swing, Speenhamland and Rural Social Relations", p. 28I. 
I83I), Eastry (Richard Dixon, executed on Penenden Heath on 22 December I 83I), Barton Stacey (Thomas Berriman, whose father was transported by the Hampshire Special Commission, and Henry Hunt, both executed at Winchester in March I 832) tended to worsen already severely tested rural social relations. ${ }^{8}$ Indeed, the use of the full powers of the state without going as far as mustering troops in all towns and major villages - a move that would have indicated civil war - did not terrorize everyone. That an incendiary fire occurred only a few miles away from Penenden Heath within hours of Dixon's execution was the strongest possible statement that the poor would not be cowed into passive quiescence. ${ }^{81}$

There was a noticeable lack of remorse in these later gallows speeches in comparison to earlier Swing execution exultations to fear God and avoid beer shops. The most forceful demonstration of this came in an extraordinarily defiant and articulate speech made by nineteen-year-old George Wren upon the Horsham scaffold in December I 832. Wren, along with his brother, had been accused of firing Uckfield vestryman Kenward's barn in June I 832 . Nothing initially transpired, presumably due to a lack of non-circumstantial evidence, but on 8 November George Wren was again apprehended. Wren, "whose conduct and levity were notorious", was subsequently indicted and found guilty at the Sussex Assizes for a crime he vehemently denied. Upon the scaffold, he launched into an extraordinary riposte:

I am brought to this fatal scaffold to be murdered [...]. I am brought to this like a bullock to the slaughter [...] what must those poor people feel, at the last moment, who brought me to this ignominious end [...]. I was condemned by the people of Uckfield, but God forbid I should accuse all the people of that parish.

Wren ended his speech by naming, and thereby shaming, those who were instrumental in his demise. ${ }^{82}$

This anger and bitterness was not reflected through a widespread resort to machine-breaking in 1832 and 1833 , excluding the aforementioned attack at Hougham near Dover on I 8 August I $833 .{ }^{83}$ Nor was it expressed through a widespread resort to striking or the mass lobbying of rural

80. Guestling: Brighton Gazette, 25 August I831; Sussex Advertiser, 19 December I83 I and 2 January 1832; Indictment of Thomas Bufford, Sussex Winter Assizes I83 I, NA, ASSI 94/ 2 I04. Eastry: W. Hughes D’Aeath, Knowlton Court, nr Wingham, to Melbourne, I 6 November I 83 I; indictment of John Dixon, Kent Winter Assizes I83 I, NA, HO 64/2, pp. 42 I-422 and ASSI 94/2098; The Times, 17 November and 24 December I831. Barton Stacey: The Times, 5 March I832; Hampshire Chronicle, I9 March I 832.

81. Kentish Gazette, 27 December I83 I and 6 January I 832.

82. Sussex Advertiser, I I June I832; Brighton Herald, I6 June, and 22 December i 832; indictment of George Wren, 19, Sussex Winter Assizes, I 832, NA, ASSI 94/2 137.

83. Kentish Observer, 22 August I 833 . Three days later an incendiary fire occurred at nearby East Langdon following much "murmuring" and "threatening insinuations" regarding some farmers mowing their wheat; Kent Herald, 22 August 1833. 
vestries. The record, as Wells has suggested, probably tends to underrepresent such acts because of the magisterial belief that a resort to the full course of their powers would tend to "regalvinise Swing" ${ }^{84}$ Notwithstanding evidential concerns, it would appear that such protests in I 832 and I 833 occurred only sporadically and without any tendency to cluster in time or space. Instead, the level of incendiarism after declining in the early months of I 832 - mirroring the experience of I 83 I - again increased dramatically in the post-harvest period. The experience of 1833 , whilst less marked than in I83 I and I832, followed a similar pattern.

\section{Swing as public discourse}

The resort to protest in the aftermath of the Swing courts of 1830 was undeniably multifaceted. It also displayed a strikingly concentrated geography, at least in relation to organized protest. Wider public, governmental, and media discourses were more straightforward. This was in no small part due to the continued, if occasional, use of the threatening monosyllable "Swing". Whilst the archive is probably defective in recording such usages (it was, after all, a pseudonym) several instances received widespread publicity in the provincial press. On 20 January I83 I farmer Humphrey at Donnington near Chichester received a "Swing" letter threatening to burn his premises if he employed his threshing machine. The letter was, presumably to reinforce the perceived threat, wrapped up in a handbill entitled the "Starvation of the Poor". Similarly, in February i 83 I, it was reported that prior to an incendiary fire, Farmer Godwin at Fareham had received "some Swing" letters. "Swing" graffiti also appeared on "most" walls and buildings in the vicinity of Dover following the reduction of labourers' wages in the surrounding villages in late May I $83 \mathrm{I}$. This was both the location and the style in which the pseudonym was first used in 1830.85

Thereafter "Swing", the protestors' pseudonym, fell into abeyance in the south-east, the sole exceptions being a "Swing" letter sent to an individual at Milton Chapel near Canterbury in obscure circumstances, and its later use, as will be shown in the next section, at Hambledon (Hampshire) in late I 83 I. ${ }^{86}$ "Swing" lived on in the public mind, both literally as the mythic leader of a quasi-insurrectionary movement of the poor and in a more diffuse way as the totem for the manifestation of broader tensions. This dynamic was partly a function of the several "instant" histories of Swing, written in the early

84. Wells, "Social Protest, Class, Conflict and Consciousness", p. I67.

85. Sussex Advertiser, 31 January I83 I; Rochester Gazette, I February I83 I; Hampshire Telegraph, 7 February I831; Reading Mercury, I4 February i83 I; Kent Herald, 26 May i83 I; Maidstone Journal, 31 May i831. For the initial use of "Swing" in I830, see Carl Griffin, "Affecting Violence: Language, Gesture and Performance in Early Nineteenth-Century English Popular Protest", Historical Geography, 36 (2008), pp. I39-162.

86. Kent Herald, 4 October I 832. 
months of $183 \mathrm{I}$, which served to keep the movement firmly in people's minds. It was also partly a function of the ability of even isolated acts of protest to reinvigorate Swing in the public mind. For instance, a letter to the Hampshire Advertiser in November I 83 I labelled the recent spate of covert protests in Wiltshire as "Swing" fires. Furthermore, as a Times report of an incendiary fire which targeted a tenant of Kentish grandee Lord Sondes at Throwley (Kent) on 30 December I 83 I exclaimed: “'Swing' is no respecter of persons, or \& noblemen so truly benevolent as Lord Sondes [...] might indeed, expect some consideration." ${ }^{87}$

Because of the heightened sense of alarm generated by the events of I 830 , commentators, and some newspaper editors, were quick to seize upon both incendiary fires and "riotous" assemblies as evidence that either Swing had been restoked, resurrected, or had morphed into some new, terrifying form. A fire in November I 832 at Riverhill, near Petworth, the location of the fire that announced Swing's arrival in west Sussex, was reported in the Brighton Herald under the banner "Swing Again". A fire at Rainham in June I83 I, combined with the aforementioned open threats of incendiarism in the Swale area, prompted the normally temperate Earl of Camden to express that there were now "[a]larming symptoms of an evil aspect" in east Kent. ${ }^{88}$ The Earl of Winchelsea was three times the victim of incendiarism, supposedly, so reckoned the Kentish Gazette, in protest at the Earl's position as Colonel of the East Kent Yeomanry. ${ }^{89}$ This heightened sense of an imminent conflagration of the rural poor also took the form of a readiness to assume dastardly motives for events that actually had innocent explanations. Whilst newspaper editors were loath to publish corrections, one such rare expression was made by the Brighton Gazette in February I 832. Initially, the paper reported that a fire on Mr Rickman's Salvington farm on 3 February was the result of incendiarism. It soon transpired that the fire was accidental, the result of a cottager throwing out some live embers. The pre-Swing reticence to assume the worst of intentions had, so it would seem, dissolved..$^{\circ}$

The word "Swing" was also deployed by Horsham radicals attempting to generate support for a "very violent" political union. Here, the strong anti-clerical spirit generated in November I830 - when an anti-tithe meeting partly planned by the Horsham Radical Society led to a major fracas in the church and churchyard - was used to build popular support to resist property being distrained for the non-payment of church rates.

87. Hampshire Advertiser, 26 November i831; The Times, 3 January I831; Kentish Gazette, 3 January i 832 .

88. Brighton Herald, 24 November I 832; Camden, Willington Street, to Melbourne, is June I 83 I, NA, HO $52 / 1_{3}$, fos $54-56$.

89. Kent Herald, 6 September I832; Kentish Gazette, 7 September I832; Maidstone Journal, I I September i 832 .

90. Brighton Gazette, 9 and I6 February I 832. 
Whilst the distrainment did occur, when the property was put up for auction not a single bid was made. The political union seized upon this failure and organized a march through the streets of Horsham, whereupon some of the reclaimed property was triumphantly paraded. Even more suggestively, they also printed a "one penny paper" which was hawked about the streets of the town entitled "Swing Redivious [sic]". Thus, the spirit of Swing was subtly reworked to launch a sustained attack upon both the established Church and the local authorities. ${ }^{9 \mathrm{I}}$

\section{Popular politicking: something after Swing?}

Horsham was by no means alone as a hotbed for radical political agitation in the autumn and winter of 1830 . As Wells has asserted, the radical political dimension of Swing was significantly underemphasized by Hobsbawm and Rudé, even if Charlesworth, in his re-analysis of their data, did suggest that activities of radicals were probably partly responsible for diffusing Swing. ${ }^{92}$

Protest activity in the vicinity of Maidstone in late I 830 was strongly informed by radical politics, not least due to the active role of radicalized shoemakers and papermakers in mobile Swing groupings. ${ }^{93}$ Similarly, Swing in the areas around Battle and Brighton was clearly infiltrated by radicalism. At Battle this was evidenced by the activities of ex-Metropolitan policeman turned revolutionary agent, Charles Inskipp, and at Brighton by an attempt to steal "eight 6 pounders" from the barracks' munitions store. ${ }^{94}$ More famously, or rather more notoriously, at Sutton Scotney in the Dever Valley, members of a "Musical and Radical Society" that met regularly in local pubs and advocated universal male suffrage were integral to local mobilizations.

91. Thomas Sanctuary, Nunnery, nr Horsham, to Melbourne, 21 October 1832; Stedman, Horsham, to Phillips, I8 November I832; Revd W. Barlee, West Chiltington, to Melbourne, 4 May i 833 , NA, HO 52/30, fos 2-3, 7-9 and 52/23, fos I $2-13$.

92. Wells, "Social Protest, Class, Conflict and Consciousness", pp. I84-187; idem., "Southern Chartism", Rural History, 2 ( I99I), pp. 37-59, 38; idem, "Mr William Cobbett, Captain Swing, and King William IV", Agricultural History Review, 45 (1997), pp. 34-48; idem, "Moral Economy of the English Countryside”, pp. 209-272; Hobsbawm and Rudé, Captain Swing; Charlesworth, Social Protest in a Rural Society.

93. Griffin, “As Lated Tongues Bespoke”, pp. 58-62, 65, 73-74, 76-77.

94. Battle: Battle Post Office Deputy, 26 November 1830, Battle Post Office, 27 November and I December I830, to Freeling, Clerks to the Battle Bench, 26 November 1830, Thomas Bellingham, 2 and 3 December i 830, to Melbourne, NA, HO 52/10, fos 430, 435-436, 437, $43 \mathrm{I}-432,440-443$ and 444 ; prosecution briefs prepared by the Treasury Solicitor in the case of the King vs Charles Inskipp, Sussex Winter Assizes, NA, TS I /1007; Brighton Gazette, 23 December I830 (assize reports). See also Wells, "Mr William Cobbett", p. 39. Brighton: Brighton Ordnance Office, to Peel, 23 November I 830, plus enclosures, Mr Dinninar, Brighton, to Sir H. Taylor GCH (forwarded to Home Office), 25 November I 830, NA, HO 52/10, fos 307-3 I I and 317-322; The Times, 20 November 1830. 
Nevertheless, there was little sense that Dever Valley Swing incidents made recourse to politically charged critiques. The plea of a group assembled at Sutton Scotney on I9 November I 830 was arguably even more demur than most Swing pleas: "we are half starved; we are willing to work, let us be paid what we earn, that's all we want!" Even the Revd Crockerton of Stoke Charity, who had been active in the attempt to bring successful prosecutions against Joseph and Robert Mason, thought that the "Meetings" had little if "anything immediately to do with the risings" ${ }^{95}$ Either way, it is impossible to dispute that in some locales plebeian radical politics inspired Swing and in some instances informed Swing's demands.

What occurred beyond the repression of 1830 was rather different. Whilst meetings calling for a moderate reform of the electoral system were a major feature of civic life in southern England throughout I 83 I and $1832,{ }^{96}$ more radically charged meetings were far from obscure. Analysing the foundation of such radical societies is complicated by the tendency of the press and Home Office correspondents to conflate judicially tolerated reform unions with judicially prohibited political unions. For instance, the Kent Herald, a paper in favour of moderate reform, referred to a group of pro-active reform campaigners at Canterbury as the Canterbury Reform Union. However, the activities of this "union" were uncannily similar to those of political unions elsewhere, not least in relation to their adopted practice of sending "delegations" to nearby places to stimulate campaigning. ${ }^{97}$ Many other unions did not hide behind the cloak of ambiguity but instead proudly - and publicly proclaimed their beliefs and objectives. At Rochester, a well-established centre of radical and popular politics as far back as the I790s, the political union established in late I8 3 I openly made calls for universal male suffrage and voting by ballot. At Faversham, a group of "radicals" headed by their "recruiting sergeant", "a republican Frenchman in exile", marched to Sittingbourne on 27 October i 83 I to help frame a petition to the King expressing their disappointment at the rejection of the second Reform Bill. ${ }^{9}$

This public militancy was in many ways novel and certainly eclipsed the far more circumspect calls for radical reform in the Medway towns in

95. Southampton Mercury, 20 November 1830; Revd D. Cockerton, Stoke Charity to Sir Thomas Baring, 2 December I 830, HCRO, $92 \mathrm{M} 95 / \mathrm{F}_{2} 8 / 3$. For incidents in the Dever Valley see David Kent, Popular Radicalism and the Swing Riots in Central Hampshire (Winchester, I997), pp. 8-I4.

96. The Kentish villages of Aylesford, Charing, Stone, Chart, Leeds, Thurnham, Detling, and Sutton Valence, all near Maidstone and affected by Swing in October and November 1 830, sent petitions in support of reform to Parliament in February I83 I; Maidstone Gazette, I March I 83 I.

97. Kent Herald, i7 May i 832.

98. Kentish Gazette, I November I831. 
the 1790 s and early $1800 .^{99}$ Moreover, this burgeoning campaign was more explicit in its denunciation of the existing parliamentary system than the relatively obtuse "rights" rhetoric that had infused many of the I 830 protests. Even in locales without active political unions, individuals took their arguments to the people. For instance, at Eastbourne in November I 83 I, "a stranger" was bold enough to launch his tirade against "the Peers, Bishops, \&c" in the churchyard on a Sunday morning. ${ }^{.00}$ This growing clamour, combative in both organization and in terms of its overt profile, was in large part a function of the floundering of the second Reform Bill in October I 83 I. The unsuccessful vote was, as Wells has suggested, evidence that the calls of moderate reformers had not been heeded but that a more strident approach may reap dividends. ${ }^{\text {IOI }}$ Thus, a "very peaceable" meeting of the Winchester operatives at Oram's Arbour in early November i 83 I demanded "Universal Suffrage - Vote by Ballot and no property qualifications". Nine months later political unions in the vicinity of Winchester (see below) were actively politicking in the I 832 General Election to get Henry Hunt's son elected in place of popularly despised local grandee and banking magnate, Bingham Baring. ${ }^{\mathrm{I}}$

The growing strength of political unions stoked a deep-seated fear amongst many employers and the magistracy that they could utilize their platform for a far wider Swing-like tumult. In part, this stemmed from the hierarchical, national organizational frame deployed by the political unions: "parent" unions were affiliated to, initially, the London Union and later on the "Birmingham and National Union" and in turn were charged with founding local satellite unions. ${ }^{103}$ Even the government's 22 November I83 I proclamation, issued under the auspices of the 1799 Corresponding Societies Act, that political unions were "unconstitutional and illegal" did little to quell the ardour of south-eastern unions.

The other reason for such deep-seated fears was the apparent ease with which satellite unions were founded in even very small rural communities.

99. John Gale Jones, A Political Tour Through Rochester, Chatham, Maidstone, Gravesend Ec. (Rochester, 1796/1997).

ıоo. Hampshire Advertiser, 29 October and S November I831; Poor Man's Guardian, I8 August I 832 .

ıог. Wells, "Social Protest, Class, Conflict and Consciousness", pp. I88-i 89.

I02. Hampshire Advertiser, I 2 November I831; i August i 832. For an analysis of Hampshire (high) politics in this period see: Ruscombe Foster, The Politics of County Power: Wellington and the Hampshire Gentlemen I820-1852 (London, 1990). Ironically, Oram's Arbour, a longfavoured spot for plebeian political meetings, was subsequently the site upon which the popularly loathed Winchester New Poor Law Union was built. Thus, a space of emancipation became inscribed as a space of incarceration.

I03. At a meeting of the revived Brighton Political Union in June I 832, earlier incarnations having floundered in the face of internal fissures, one man was reported to have read out the "Birmingham Declaration"; Hampshire Advertiser, 3 September I83 I; Brighton Gazette, 21 June I832. 
Nancy Lopatin's now standard work on political unions details the existence of south-eastern unions at Brighton, Ramsgate and Thanet, Sittingbourne, Winchester, but not the multitude of small rural unions. Indeed, Lopatin claims "there is no indication that Political Unions included agricultural labourers", and that "urban and commercial interests" were dominant amongst political union membership. ${ }^{104}$ But south-eastern unions were far more extensive than Lopatin suggests, penetrating even small country parishes. These unions also developed in a very different local political context to the better-known unions in the urban English Midlands. These southern unions matter to accounts of both rural protest and the wider reform movement because of the apparent readiness for even field workers and rural artisans to embrace constitutional politicking as a protest strategy.

The union at Brighton was initially founded on 29 August I 83 I by a group of local operatives as a branch of the London Union. The Brighton "delegates", in turn, were instantly active in spreading their message to the nearby towns and villages. As the Brighton Gazette harrumphed: "The delegates doubtless find riding about the county and making speeches more agreeable and more profitable than work". ${ }^{105}$ The attempt to revive the union in the summer of I 832 was also founded upon "missionary" work, five "branches" existing besides the "parent society" based at the Bricklayer's Arms. Whilst this initial effervescence was short-lived, retreat swiftly following revival, a visit by Poor Man's Guardian publisher, Henry Hetherington, in October 1832 led to a renewed enthusiasm for campaigning. ${ }^{106}$ In conjunction with a satellite union at Uckfield, which presumably dated from the summer campaign, the Brighton Union helped found a union "on political subjects" at Horsted Keynes in November I 832 (see Figure 5 overleaf). Despite attempts to suppress the Horsted Keynes Union, by, rather bluntly, using the Riot Act, similar meetings continued well into I 833. At nearby West Chiltington, a union was founded which was linked "to the one in Billingshurst, which is a branch of a very violent one in Horsham". It met every Wednesday at "the house of a publican whose principles of both politics and religion are notorious", the pub having been the scene of "a violent riot $[\ldots]$ in November I 830 ". ${ }^{107}$

104. Nancy Lopatin, Political Unions, Popular Politics, and the Great Reform Act of ${ }_{1} 832$ (London, I999), p. 168.

I05. Brighton Gazette, I September I83 I; Hampshire Advertiser, 3 September I831.

106. Brighton Gazette, 21 June, and 26 July i 832; Brighton Herald, I3 October, and Io November I 832 .

107. Poor Man's Guardian, 20 October 1832; Brighton Herald, 24 November 1832; Sussex Advertiser, 26 November, and 3 December 1832; W. Mabbott, Uckfield, to Melbourne, 20 November I 832; Revd W. Barlee, West Chiltington, to Melbourne, 4 May I833, NA, HO 52/20, fos II-I 2 , and $52 / 23$, fos $I 2-I 3$. 


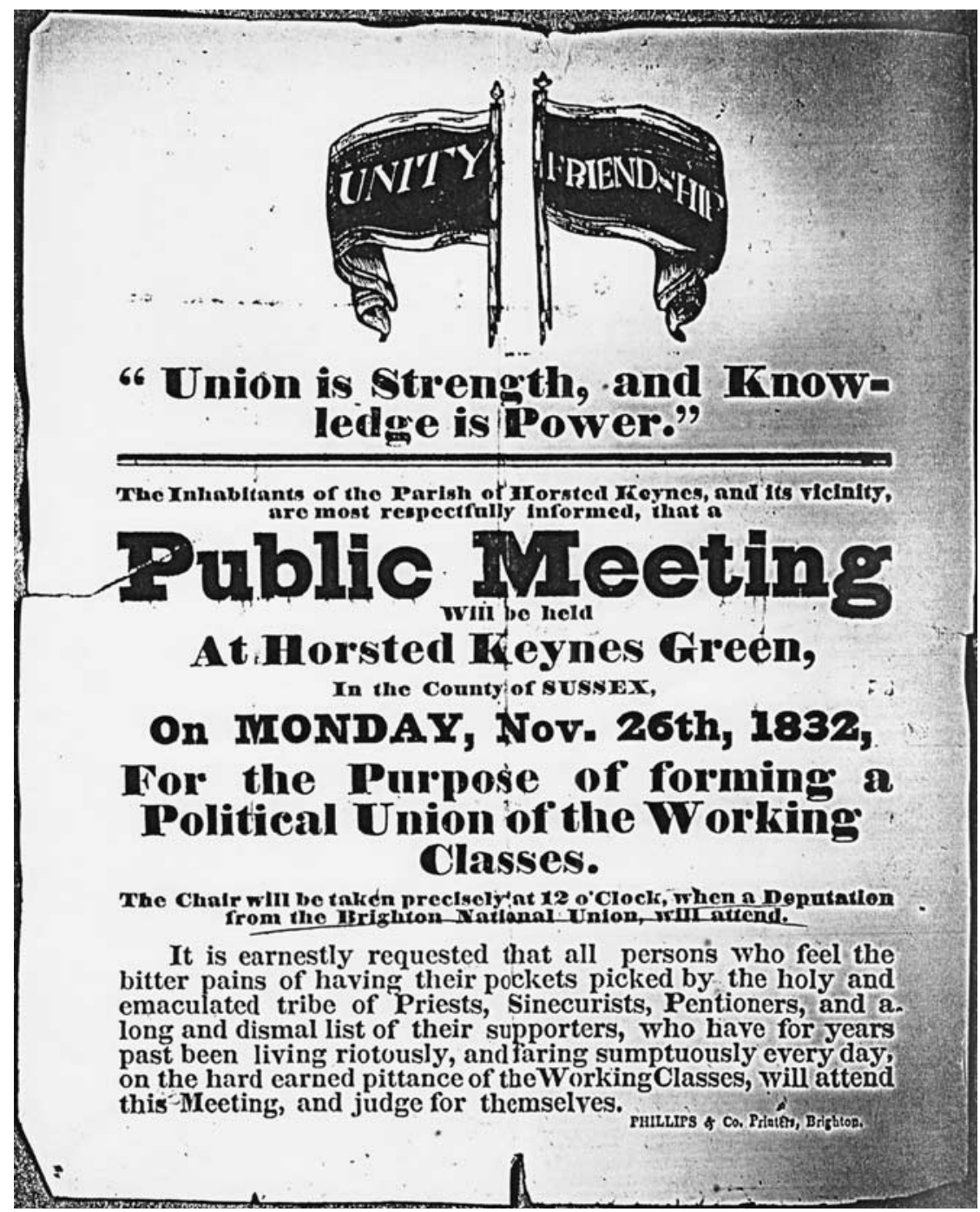

Figure 5. Handbill advertising a public meeting to form a political union at Horsted Keyes on 26 November I 832.

The National Archive. Used with permission.

The Winchester Union too was active in founding satellite unions in surrounding villages. The Dever Valley was, again, well-represented. Perhaps in part inspired by Cobbett's "Chopsticks Festival" - held symbolically at Sutton Scotney in July I 832 to "celebrate the fall of the 
villainous boroughmongers" ${ }^{108}$ - the villages of Wonston and Sutton Scotney, Bullington and Barton Stacey were all covered by a union. Further north of Winchester, several villages, including Chilbolton and Wherwell, also hosted unions. Newport hosted the Isle of Wight Political Union as early as the autumn of I83 I, and was soon active in helping found an affiliated union at nearby Ryde. Even tiny Itchen Abbas, home of the Duke of Buckingham and Chandos, who had earlier spoken out in the Lords against the Birmingham Union, was home to a political union. ${ }^{109}$ According to Hampshire Lord Lieutenant the Duke of Wellington's rural informers, as many as half of all Hampshire labourers were thought to be involved "in the clubs". In light of the events of I 830, this perception made the farmers "a good deal alarmed" by the potential of large assemblages of labourers. Thus, at Chilbolton on 28 October I 832, thirteen labouring members of the political union were discharged by their employers and on applying to the overseer - "one of the tyrantslaves" - were refused relief. ${ }^{\text {II }}$ This was not, according to Colonel William Iremonger, JP, "only a matter of wages", for the labourers will "ready to follow anyone, who will lead them into mischief - indeed 'mischief' is their motto". ${ }^{11}$

The perennially disturbed east Hampshire parish of Hambledon was another centre of political union activity. It is unclear as to whether the "Hambledon Independent Union Society" was truly independent or was connected to other larger unions elsewhere. Either way, it is clear that it was a vibrant, well-organized and politically astute group. One of two placards placed up in the "town", one in November I83 I and another on 5 January I 832, warned that if any member of the union was prosecuted "the hand of Burke or Swing will be put in force against the prosecutor". The purpose of the union, so claimed the placards, was to "eradicate

I08. Cobbett's visit, though symbolic, was part of a wider tour of market towns. His purpose was to remind people that the Bill would be "a bundle of waste paper" unless the newly enfranchised campaigned for further change. His purpose was therefore to campaign for "a common understanding amongst the people, with regard to what measures ought to be adopted by the reformed Parliament", Cobbett's Political Register, 30 June I832; Brighton Gazette, 26 July I 832; Sussex Advertiser, 6 August I 832. According to Ian Dyck, Melbourne thought the Chopsticks' Festival to be "a seditious affair", but as no report of the festival was made no prosecution could be brought; Ian Dyck William Cobbett and Rural Popular Culture (Cambridge, 1992), pp. 198-199.

109. The Times, 6 October I831; Hampshire Telegraph, 24 October i 831; Wells, "Social Protest, Class, Conflict and Consciousness", pp. I89-190.

I го. Dyck, William Cobbett, p. I98; Poor Man's Guardian, I December I832. In May I832 when an attempt was made to found a political union at Salisbury (Wiltshire), the "Masters" resolved not to employ any members; Hampshire Advertiser, I9 May I 832.

I I I. Sir J.W. Pollen, Redenham House, Andover, to the Duke of Wellington, enclosing Colonel William Iremonger, JP, Wherwell Priory, to Pollen; University of Southampton Special Collections, $\mathrm{WP}_{4} / 4 / 3 / 34$ 
Tyranny oppression and petty interferences" and to apply "the rules of common sense". The combining of Swing with radical politics was made even more explicit after an incendiary fire occurred on 3 January: if a prosecution took place "for the fire", there would be "a worst disaster". The notice was signed "The true Hambledon Union or Swing". Lord Melbourne duly responded to local demands for help with the offer of a £500 reward, the same amount offered in King William's Swing proclamation. ${ }^{\text {I } 2}$

Whilst the record suggests that urban political unions remained active until the summer of $1834,{ }^{\mathrm{II}} 3$ it would appear that rural unions fell into abeyance in the second half of 1833 . Whilst further micro studies are required to find out whether the same individuals and families were involved, it is surely telling that many of the rural areas which witnessed anti-New Poor Law protests had also been hotbeds of Swing activity and had subsequently hosted political unions. Thus in the south-east, the Swale and Medway area, the area between Battle, Rye, and Hythe, the area between Brighton and Horsham, and the Dever Valley, all witnessed the most trenchant and bitter protests. ${ }^{\mathrm{II}}{ }^{4}$ Indeed, demonstrations of collective force continued in the latter place between the collapse of the political unions and the onset of anti-New Poor Law protests. On 3 June I 834, about 200 people gathered at Micheldever to listen to speeches given by two local labourers. Whilst the exact purpose of the gathering is unclear, the tenor of extant reports suggests popular politicking. Not only was the size of the audience extraordinary, so too was the fact that despite the intervention of the Micheldever "policeman", Thomas Ellery, the crowd refused to disperse. As one of the speakers, John Rhide, proclaimed "[l $\left.\begin{array}{ll}\mathrm{d} & \mathrm{do}\end{array}\right]$ not care much for magistrates, prisons, police or constables: [I have] been in prison once but would not go again". ${ }^{\text {II }}$

It is also possible that the Micheldever meeting represented a spilling over of political-union activity into nascent trade-union activity. As (famously) was the case at Tolpuddle in neighbouring Dorset, it is possible that activists in the Dever Valley had also made contact with delegates from the Grand National Consolidated Trades Union (GNCTU). ${ }^{\text {II } 6}$ As Wells has shown, the GNCTU on its foundation made a deliberate policy of "try[ing] to get up a Union among the agricultural labourers"

I I 2. T. Butter, Hambledon, to Melbourne, 6 January I 832 ; TNA, HO 64/3, fos $70-73$.

I I 3. For instance, the Maidstone Political Union was still petitioning parliament as late as July I834; Cobbett's Weekly Political Register, 26 July i 834.

I I4. See Griffin, “'As Lated Tongues Bespoke”, ch. 9; Wells, "Resistance to the New Poor Law”, pp. 9I-I 26.

I I s. Warrant for the arrest of Edward Bishop and John Rhide for leading an illegal gathering in Micheldever on 3 June $1834 ; \mathrm{HRO}, 92 \mathrm{M} 95 / \mathrm{F}_{2} / \mathrm{I}_{3} / 3$.

i 16. Joyce Marlow, The Tolpuddle Martyrs (London, I971), pp. 43, 46. 
and, elsewhere in the south-east, had some success at getting fieldworker recruits to urban branches. For instance, in the spring of 1834 , labourers reportedly "flocked" to join the GNCTU at Brighton. ${ }^{117}$ There is plenty of evidence to show that in rural Hampshire the line between political unions and trade unions was infinitesimally thin. When farmer Allec of Somborne had attempted to reduce his workers' wages from ios to $9 \mathrm{~s}$ a week, he was met by the claim that his labourers had received directions from "the union" not to accept less than ios, and that the union would "support" them. Indeed, according to Colonel Iremonger, labourers who joined the political unions thought that their subscription of Id a week supported one of two causes: either "to purchase ammunition, others, to overawe the government in compelling them to come into their views", or, "the general impression", "to keep up a certain rate of wages". ${ }^{\text {I8 }}$

Either way, defiance in the face of continued repression not only taught labourers how to organize and innovate in the arts of resistance but also to assume a quite different set of everyday social relations than those that Swing had sought to restore. As Assistant Poor Law Commissioner Sir Francis Head remarked of the labourers of the vicinity of Dover: "In no enemy's country that we have seen have we ever encountered the churlish demeanour which these men, as one meets them in the lanes, now assume." ${ }^{\prime \prime 9}$

\section{CONCLUSION}

As social-movement theory models predict, there was no clearly defined end to Swing. Nor was there a neat, linear decline. Instead, the protests that followed were fractured in space, time and protest technique. Swing also took on a phantasmagorical quality. For even when an area remained free from Swing-like protests, the fear generated in I830 converted Captain Swing into a spectral presence that continued to wreak terror upon the minds of farmers and the rulers of rural England. Over and above Swing's continuities and revivals, it was as a concept that Swing most meaningfully lived on. Thus in I 852 at a public meeting on the Isle of Wight, one speaker juxtaposed the (relative) rural prosperity of the early i 850s with the time "a few years ago, when Swing was abroad and incendiary fires and public prosecutions for riot were rife". Swing was even raised as a fearful spectre during the Revolt of the Field in the I870s. No less a pillar of the establishment than the Right Honourable

I 17. Roger Wells, "Tolpuddle in the Context of English Agrarian Labour History, I780-1 850 ", in John Rule (ed.) British Trade Unionism: The Formative Years (London, I988), pp. I 2 I-I 22. i 8 . Sir J.W. Pollen, Redenham House, Andover, to the Duke of Wellington, enclosing Colonel William Iremonger, JP, Wherwell Priory, to Pollen; University of Southampton Special Collections, $\mathrm{WP}_{4} / 4 / 3 / 34$.

i 19. Kent Herald, 7 May i 835 . 
J.W. Henley, veteran Oxfordshire MP and onetime President of the Board of Trade, proclaimed at the annual dinner of the Oxfordshire Agricultural Society in May I872:

He had no doubt that some of them would recollect the "Swing" riots about forty years ago [...]. We had reason to bless ourselves now that, instead of the question being raised by breaking of machinery and burning their homesteads, the persons had come forward more quietly, though in some cases they had had agitators among them. ${ }^{\mathrm{I} 20}$

The post-repression response was, in short, far more complex than Hobsbawm and Rudé suggested. It was not simply manifest through physical protests, instead it assumed a far greater complexity in the ways in which residual memories of 1830 were continually remapped in response to physical protests. In this sense, Swing was not a static threat but something that was constantly morphing and coming into being. There can be little doubt that the real, as much as the perceived, threat of Swing's talismanic forms of machine-breaking and incendiarism declined post-repression - and markedly during I 833 . Moreover, the response to both repression and the reneging of agreements forged in the heat of late I 830 represented a genuine evolution. This was made evident not only in the ways in which the internal balance of rural workers' repertoires of resistance altered, but also in the arguably more dramatic shift in tone. As Peter Jones has suggested, ultimately Swing sought to embrace not only the fieldworkers and rural craftsmen but the farmers too. Post-December I 830 what evolved was based on the unity of rural working people but the exclusion of their employers. ${ }^{\text {II }}$ As Sir Francis Head perceived, not only had the tone of labourers' protests evolved but so had their everyday demeanour. What developed, albeit unevenly, between I 83 I and I 833 was a new agrarian equipoise built on mutual fear: the Lucifer and Swing's spectre counterbalanced by the gallows and the hulks. On a day-to-day level, the field workers' displayed what Keith Snell has labelled a "deferential bitterness", something evident before Swing but defiant post-I $830 .{ }^{\mathrm{I} 22}$

To an extent, this model is too simplistic. The geography of protest in the post-repression period suggests something more complex. In some locales, Swing lived on long after the Assizes and Special Commissions

I20. Hampshire Telegraph, I7 April I852; Richard Hooper, "Henley, Joseph Warner (1793-I 884)", Revd H.C.G. Matthew, Oxford Dictionary of National Biography (Oxford, 2004), http://www.oxforddnb.com/view/article/I2929, accessed 7 March 2008; Jackson's Oxford Journal, 25 May 1872.

I 2 I. Jones, "Swing, Speenhamland and Rural Social Relations", pp. 289-290.

I22. K.D.M. Snell, "Deferential Bitterness: The Social Outlook of the Rural Proletariat in Eighteenth and Nineteenth Century England and Wales", in Michael Bush (ed.), Social Orders and Social Classes in Europe since I 500: Studies in Stratification (London, 1992), pp. I 58-1 84. 
had terminated their bloody business upon the scaffold. This was, as noted, partly a response to the severity of the judicial repression which impacted disproportionately upon some locales than others. But it was also a response to the localized cutting of wages and the use of threshing machines. This pattern was further complicated by the fact that even in some areas where protests persisted they took on a different form to that adopted during the autumn and winter of 1830 . Thus, in the area operated by the Elham gang in 1830 , the destruction of threshing machines backed up with the resort to incendiarism against those who sought to prosecute machine-breakers persisted as the main constituents of the plebeian repertoire of resistance. In the area around Chichester, protests shifted from the destruction of threshing machines to open wages agitations and incendiary attacks on the users of machinery. Moreover, in those areas where protest was either clearly snuffed out or had ran its course in I 830 , the protests that occurred between I 83 I and I 833 did not necessarily fit any neat model. In some locales, these protests clearly were adopted in a framework that for all intents and purposes suggested Swing redivivus. In other areas, protests were palpably different in tone and more divisive than the consensus that Swing sought to generate.

There is no one model that can be applied to south-eastern England. Swing lived on in some locations and figuratively in most places. In some locales, Swing - or something like Swing - revived. In other places, protests assumed a defiantly post-Swing hue. As Doug McAdam has suggested, the success of social movements tends to be local and the medium and long-term effects more cultural than policy-specific. ${ }^{\text {I23 }}$ Moreover, in some places Swing's message morphed into something different, even though the activists remained the same. Whether in other locales where Swing flared brightly this pattern would be any different is impossible to assess without systematic analysis. But even a cursory search through the archives of Berkshire, Dorset and Wiltshire, the other most important "Swing" counties, suggests a similar, if less intensively overt, scenario.

What is beyond reasonable doubt is that the repression of the protests of I 830 did not, as Hobsbawm and Rudé claimed, "[destroy] what remained of the labourers' will to resist". Nor was, as the Hammonds claimed, "the movement crushed". ${ }^{24}$ Indeed, it is clear that the will to resist was just as strong between I8 3 I and I 833 as it had been in late I 830. That many labourers were willing to dispute their wages, openly question the nature of authority, and even join forbidden political unions,

I 23. Doug McAdam, "Culture and Social Movements", in Enrique Laraña, Hank Johnson, and Joseph Gusfield (eds), New Social Movements (Philadelphia, PA, I994), pp. 36-57.

I 24. Hobsbawm and Rudé, Captain Swing, p. 281; Hammond and Hammond, The Village Labourer, p. 199 . 
is testimony to a collective will that refused to be beaten into submission by the combined might of capitalist "logic" and state terror. The "movement" evolved. Swing, as a protest movement, had meaningfully fizzled out in most places by the end of I 83 I and everywhere by the end of I 833 .

In a sense, Swing did not die - even after I 833. The full implementation of the New Poor Law from the spring of 1835 provoked the rural poor to the Swing-like combination of semi-organized open protest and affiliated covert protests. In other senses too, these protests were Swing's last-stand: they represented the last attempt before the i 870 s to restore rural communities' economic and social equipoise. Also, the broad-based coalition of labourers, artisans and farmers achieved in some locales during Swing, was, again, seemingly possible. Only the most opulent farmers welcomed the New Poor Law. But not once during the anti-New Poor Law protests did these groups openly combine. This failure to coalesce was a result of farmers backtracking in I $83 \mathrm{I}$ and $\mathrm{I} 832$ from agreements made in late 1830 . This, as noted, tended to widen the gap between employers and employees, something evidenced by the strong proto-unionist mentality evident in protests between I83I and I833 and the adoption of rural trade unionism in I834 and I835. Arguably, it was not through these protest forms that Swing informed popular protest in the later I830s. Instead, it was through the persistence of both the increased resort to incendiarism, as evidenced between I83I and I833, and in urban-sponsored national popular political campaigns. The Chartist and, to a lesser extent, Anti-Corn Law League missions made significant inroads into the south-east, though neither had the localized impact of Swing. Ultimately, the failure of rural trade unionism and the disjointed nature of anti-New Poor Law protests made the resort to the tools of rural terror and the reliance on urban missionaries almost the only feasible tools of protest left to rural workers in the late I 830 and in the early decades of Queen Victoria's reign. 